Some Aspects of Poverty in Sri Lanka: 1985-90

Gaurav Datt

Dileni Gunewardena
Poverty in Sri Lanka is still targely a fural phenomenon. Between 1986 and 1991 . national poverty rates declined modestly, atmost entrely because of a decline in rural poverty. During the same period, uban poverty increased. Poorer households tend to have higher

dependency ratios, fewer years of schooling. lower participation in the later. force, and significanty higher unemployment

The World Bank

Policy Research Department

Poverty and Human Resources Division 
POLICY RESFARCH WORKING PAPER 1738

\section{Summary findings}

Datt and Gunewardena characterize poverty in Sri Lanka, using data from two recent household surveys (for 1985-86 and 1990-91). Poverty rates in 1990-91 were highest in the rural sector and lowest in the estate sector, with the urban sector in between.

Between 1985-86 and 1990-91, national poverty declined modestly, almost entirely because of a fall in rural poverty (although poverty in the estate sector also declined). Agriculture, forestry, and fishing accounted for about 80 percent of the decline in national poverty. Favorable redistribution and growth in rural mean consumption accounted about equally for the decline in rural poverty.

During the same period, urban poyerty increased.
But poverty in Sri Lanka is still largely a rural phenomenon. Nearly half the poor depend on agriculture for livelihood. Another 30 percent depend on other tural nonagricultural activities.

Regional variations in poverty are fairly limited. Female-headed households are associated with greater poverty only in the urban sector. Poorer households tend to have higher dependency ratios, fewer years of schooling, lower rates of participation in the labor force, and significantly higher rates of unemployment.

Direct transfer benefits from the Food Stamp Program are progressive and have a greater impact on poverty than uniform allocations from the same budget.

Economic growth could reduce poverty considerably.

This paper - a product of the Poverty and Human Resources Division, Policy Research Department - is a revised version of a background paper for the Sri Lanka Poverty Assessment. Copies of this paper are available free from the World Bank, 1818 H Street NW, Washington, DC 20433. Please contact Patricia Sader, room N8-040, telephone extension 202-4733902, fax 202-522-1153, Internet address psader@worldbank.org or Andrea Ramirez, room N8-036, telephone 202-4585734. March 1997. (62 pages)

The Policy Research Working Paper Series disseminates the findings of work in progress to encourage the exchange of ideas about development issues. An objective of the series is to get the findings out quickly, even if the presentations are less than fully polished. The papers carry the names of the authors and should be cited accordingly. The findings, interpretations, and conclusions expressed in this paper are entirely those of the authors. They do not necessarily represent the view of the World Bank, its Executive Directors, or the countries they represent. 


\title{
Some Aspects of Poverty in Sri Lanka: 1985-90*
}

\author{
Gaurav Datt and Dileni Gunewardena
}

* This is a revised version of a background paper in support of the Sri Lanka Poverty Assessment which was written by the authors at the Poverty and Human Resources Division, Policy Research Department, World Bank. We are grateful to the Department of Census and Statistics, Ministry of Policy Planning and Implementation, Colombo, Sri Lanka, who provided us with the data as well as prompt answers to our subsequent queries. We have benefited from the comments of Hugo Diaz at various stages of the work. We would also like to thank Benu Bidani, Emmanuel Jimenez and Martin Ravallion for useful suggestions and comments. 



\section{Introduction}

Sri Lanka's record as a relatively poor country with excellent social indicators has held an important place in policy discussions on poverty and human development. Its experience has often been considered an eminent example of "support-led" as distinguished from "growth-mediated" strategy to improvement in basic capabilities (Dreze and Sen, 1989), though this view has not gone uncontested. In particular, there has been much debate on the relative importance of growth in average incomes and social sector spending for improvements in basic social indicators such as life expectancy and under-5 mortality. ${ }^{1}$ This debate has however remained largely uninformed by how the country has fared in terms of income or consumption poverty. This is for good reason: despite the apparently large poverty-oriented literature, there remain large gaps in what we know about income or consumption poverty in Sri Lanka.

For example, poverty estimates for Sri Lanka have seldom gone beyond the disaggregation for rural, urban and estate sectors, and there does not seem to exist any consistent regional poverty profile for the country. We also do not know how levels of poverty vary by socio-economic characteristics such as the sector of employment, gender of the head of the household, or ethnic groups. Similarly, little is known about the relationship between consumption poverty and other household attributes such as educational attainment, labor force participation or employment status. Also, we do not know much about recent changes in poverty and what the proximate determinants of those changes may have been.

This paper attempts to fill some of these holes in our knowledge of consumption poverty in Sri Lanka. The paper is based on an analysis of data from two recent household surveys in Sri Lanka, viz., the Labor Force and Socio-economic Survey (LFSS) of 1985-86 and the Household Income and Expenditure Survey (HIES) of 1990-91 conducted by the Department of Census and Statistics (DCS). The DCS surveys have been the basis of several previous estimates of poverty, but have remained under-utilized for a detailed characterization of poverty in Sri Lanka.

The paper is organized as follows. We first discuss the data and methodological issues related to

' The many contributions in this debate include Isenman (1980), Sen (1981, 1988), Bhalla and Glewwe (1985, 1986), Ravallion (1987), Bhalla (1988a,b), Anand and Kanbur (1991), Kakwani (1993), Aturupane, Glewwe and Isenman (1994). 
poverty measurement in section 2 . Section 3 deals with the construction of spatial and temporal cost of living indices, an issue which has been largely ignored in the empirical poverty literature on Sri Lanka. The detailed results are presented in sections 4-6. Section 4 presents our estimates of absolute poverty for 1985-86 and 1990-91 at the national and sectoral level, and examines the robustness of the observed changes in poverty over a range of poverty measures and poverty lines. It also presents results on the proximate sources of changes in poverty using some simple decompositions. In section 5 , we present a detailed regional and socio-economic poverty profile. In section 6 , we use the data to examine the targeting performance of the Food Stamp Program which has been a key anti-poverty program in the country. We also look at the implications of the poverty profile for targeting resources and development programs, and the potential effect of economic growth on future poverty reduction. The final section concludes with a brief summary of the main findings.

\section{Data and methodology}

\subsection{The standard of living indicator}

Unlike a lot of recent work on poverty in Sri Lanka, we will be concerned with consumption poverty. In particular, we use per capita consumption expenditure (excluding expenditure on durables) as the preferred indicator of individual standard of living. ${ }^{2}$ A number of recent studies have used calorie intake or food expenditure per capita (or per adult equivalent) as the poverty indicator. Examples of the former are Sahn (1987), and Rouse (1990); examples of the latter include Anand and Harris (1985), and Edirisinghe (1990). Partly, the motivation for this has been the non-availability of a suitable cost-of-living index; using calorie consumption or food expenditure linked with some caloric intake obviates the need for a cost-of-living index. But this is achieved at some expense; what these studies measure is the extent of under-nutrition or food poverty. While this is an important dimension of poverty, the poor, by most definitions, devote a significant part of their expenditure to non-food items. For instance, for 1985-86

\footnotetext{
2 See Deaton (1995) for a discussion of the relative merits of using per capita consumption as the individual welfare indicator for developing countries.
} 
Rouse (1990) reported the average share of food expenditure for the poor (defined in terms of calorie consumption per adult equivalent) to be only about 61 per cent. Arguably, an important dimension of poverty is potentially lost by ignoring non-food expenditures altogether. And there may also be considerable re-ranking of households when per capita food, rather than total, expenditure is used as the welfare indicator (see Glewwe and van der Gaag 1990, Chaudhuri and Ravallion 1994, Lanjouw and Lanjouw 1996). Total (all-commodity) consumption expenditure is also better grounded in consumer theory as a money metric of welfare, while the same cannot be said of food expenditure. Total consumption expenditure is thus preferred as an indicator of the standard of living and poverty as it allows us to construct a more generalized measure of deprivation. The lack of suitable inter-regional or intertemporal price indices for Sri Lanka is, however, a serious problem. How this may be addressed using the LFSS and HIES data is discussed further below.

\subsection{Coverage and Comparability}

The 1985-86 Labor Force and Socio-economic Survey (LFSS) and the 1990-91 Household Income and Expenditure Survey (HIES) are broadly comparable in design and methodology, though the 1990-91 survey, as its changed title suggests, is narrower in scope and has only limited information on household employment and earnings.

An important limitation of the survey data we are using should be noted at the outset: they do not have full national coverage. The 1990-91 HIES could not be conducted in 8 of the Northern and Eastern districts due to the prevailing conditions of political unrest. These districts were only partially covered in the 1985-86 HIES. To maintain comparability, we decided not to use the available $1985-86$ data for these districts. The 8 excluded districts - Jaffna, Kilinochchi, Mannar, Vavuniya, Mullaitivu, Batticaloa, Amparai, Trincomalee - accounted for about $15 \%$ of Sri Lanka's population in 1990 (DCS 1991). ${ }^{3}$

Also, data from only the first three (of the 12 monthly) rounds of the 1990-91 HIES were available

3 All references to "Sri Lanka" and "national" in various Tables and the text should be taken to imply the whole country except the 8 Northern and Eastern districts. 
to us at the time of this work. Again, in order to maintain comparability with the 1985-86 HIES, we only used data from the corresponding three rounds (i.e., pertaining to the same calendar months) of the 198586 survey. The three rounds are for the months of June, July and August.

\subsection{Poverty measures}

We will use poverty measures within the Foster, Greer, Thorbecke (FGT) class (Foster et. al 1984). The FGT class of poverty measures encompasses many of the well-known measures, and can be generally written as

$$
P_{\alpha}=\int_{0}^{z}\left[\frac{z-x}{z}\right]^{\alpha} f(x) d x \quad \alpha \geq 0
$$

where $x$ is per capita consumption expenditure, $f(x)$ is its density, $z$ denotes the poverty line, and $\alpha$ is a nonnegative parameter. Higher values of the parameter $\alpha$ indicate greater sensitivity of the poverty measure to inequality amongst the poor. We will generally work with poverty measures $P_{\alpha}$ for $\alpha=0,1,2$ which respectively define the headcount index, the poverty gap index and the (distributionally sensitive) squared poverty gap index.

\subsection{Reference poverty line}

Our starting point here is a reference food poverty line. This is derived from Nanayakkara and Premaratne (1987). Using LFSS data for $1985-86$, they estimated a food poverty line at a monthly per capita food expenditure of Rs 202.49 at 1985-86 prices, corresponding to a normative threshold of 2500 calories and 53 grams of protein per adult (age 20-39 years) male equivalent. We round this off to Rs. 200 (at 1985-86 prices), and that defines our reference food poverty line. Allowing for basic non-food expenditure estimated from national Engel functions for 1985-86 (see discussion below), this yielded a national reference poverty line of Rs 242.06 of monthly per capita expenditure (on all items except consumer durables) at 1985-86 prices. Most of our poverty estimates are anchored on this poverty line; 
often we will also use a more generous poverty line that is 20 per cent higher than the reference line. ${ }^{4}$

How does this reference poverty line compare with some others in the literature? As mentioned above, a good part of the literature on poverty in Sri Lanka does not use expenditure poverty lines at all as it performs all calculations in terms of calories. In recent work, there are only a few instances of the use of expenditure poverty lines. Notable among these is the poverty line by Gunaratne (1985), also used by Anand and Harris (1985), and Bhalla and Glewwe (1985). This is a food poverty line defined by a food expenditure of approximately Rs. 70 per capita per month at $1978-79$ prices, or about Rs. 173 at $1985-86$ prices when up-dated by the Colombo Consumer Price Index (CPI) for Food. This is about 13 per cent lower than the reference food poverty line we use. A comparison can also be made with the a-dollar-a-day (per person at 1985 purchasing power parity) poverty line used in some recent estimates of poverty for the developing world (see, for example, Chen, Datt and Ravallion, 1993). In Sri Lankan currency, this translates into a per capita expenditure of about Rs 252 per month, or about 4 per cent higher than our reference poverty line.

In some of the following analysis, we will focus on robust ordinal comparisons of poverty, for instance, when looking at whether poverty has decreased or increased between 1985-86 and 1990-91. In these cases, we will not use any specific poverty measures or poverty lines, but instead draw upon the dominance approach following Atkinson (1987), which allows us to make robust poverty comparisons for a broad class of poverty measures and for a range of poverty lines up to some quantifiable maximum.

\subsection{Regional disaggregation}

The level of regional disaggregation of the poverty profile is constrained by the overall sample size. Since we are using only 3 rounds of the surveys, our effective samples are relatively small: 4847 households for $1985-86$ and 4650 for 1990-91. It will thus not be possible to construct poverty profiles for each of the 17 districts covered in the two surveys with any reasonable degree of precision. But we

\footnotetext{
4 In some of the tables below where we use both poverty lines, we designate the population below the higher line as poor, and those below the reference line as ultra poor.
} 
do introduce a limited disaggregation broadly at the provincial and sectoral level. We distinguish the following five regions: (i) Western (districts: Colombo, Gampaha, Kalutara), (ii) Central (districts: Kandy, Matale, Nuwara Eliya), (iii) Southern (districts: Galle, Matara, Hambantota), (iv) North western and north central (districts: Kurunegala, Puttalam, Anuradhapura, Polonnaruwa), and (v) South central (districts: Badulla, Monaragala, Kegalle, Ratnapura). For each region, we further distinguish between the rural and urban sectors. Given the relatively small number of observations for the estate sector, we subsume it under the rural sector. For the estimates constructed at the national level though, we will separate out the estate sector.

\section{Spatial and temporal price indices}

For Sri Lanka, there do not exist any suitable price indices to control for (a) regional differences in the cost of living, and (b) temporal changes in the cost of living within regions or sectors. The only established consumer price index (CPI) is the Colombo CPI, which of course is a temporal price index for the city of Colombo only. The DCS also publishes urban retail prices of some food items by district. But no indices or price data are available for the rural sector. The first part of our work is therefore devoted to the construction of spatial and temporal price indices for rural and urban sectors of the five regions introduced above, using the LFSS/HIES data. This is done in two steps. First, we construct spatial price indices separately for 1985-86 and 1990-91; for either survey year, these indices link regional cost of living to national (average) cost of living in the same year. The procedure for constructing spatial price indices is the same for both $1985-86$ and $1990-91$. We then construct a temporal price index to link national cost of living in 1985-86 with that in 1990-91. Together this yields a full set of price relativities across all regions and over the two survey periods. The details of our methodology are set out below.

\subsection{Spatial price indices}

The LFSS/HIES provide data on the quantities and values of over 200 food items for the sampled households, using which one can construct unit values. For most non-food items, however, such unit 
values cannot be constructed because either we do not have data on the quantities consumed for these items, or the non-food item is intrinsically too heterogenous for a unit value to be meaningful. Thus, we begin by first constructing a spatial food price index. Spatial cost of living differences for non-food items will be estimated separately by estimating Engel functions for non-food consumption (discussed later). Our methodology for the construction of the spatial food price index for a given survey year is as follows.

(i) The entire (national) sample is ranked by nominal per capita expenditure (net of expenditure on durables), and a sub-sample of the bottom $40 \%$ of the population is identified as the reference group of households. Data from this sub-sample only are used for the construction of the food price index.

(ii) The selected sub-sample is allocated to the rural and urban sectors of the five regions, which defines the reference group of households for each region-sector.

(iii) The over-200 food items are aggregated into 38 expenditure categories, comprising 36 food categories, and kerosene and firewood. The aggregation seemed desirable for mitigating the problem of the unit values for some food items being based on very few observations for the reference group of households. An attempt has however been made to ensure that the categories consist of relatively homogenous items for both surveys. For convenience, we will refer to these 38 categories as "food", and all other items of consumption as "non-food", even though "food" includes two non-food items (kerosene and firewood), "non-food" includes some of the highly heterogenous food items. A list of the expenditure categories is given in Annex 1.

(iv) Next, we construct regional and national unit values for the 38 food categories. For region $R$, the unit value for category $j$ is defined as

$$
p_{j}^{R}=\bar{v}_{j}^{R} / \bar{q}_{j}^{R}
$$

where $\bar{v}_{j}^{R}$ is the average value and $\bar{q}_{j}^{R}$ is the average quantity of category $j$ consumed by the reference group of households in region $R$. Similarly, the national unit value for category $j$ is defined 


$$
p_{j}^{*}=\bar{v}_{j}^{*} / \bar{q}_{j}^{*}
$$

where $\bar{v}_{j}^{*}$ and $\bar{q}_{j}^{*}$ are averages for the national reference group of households.

(v) The food price index in region $R$ relative to the nation as a whole is then defined as

$$
P_{F}^{R}=\frac{\sum_{j} \bar{q}_{j}^{*} p_{j}^{R}}{\sum_{j} \bar{q}_{j}^{*} p_{j}^{*}}=\sum_{j} w_{j}^{*}\left(p_{j}^{R} / p_{j}^{*}\right)
$$

where $w_{j}$ 's are the expenditure shares of different food categories for the national reference group of households, and are defined as

$$
w_{j}^{*}=\bar{v}_{j}^{*} / \sum_{j} \bar{v}_{j}^{*}
$$

There are two reasons why we base the food price index on data pertaining to the bottom 40 per cent reference group of households only. The first reason has to do with the fact that unit values are not prices. The most important problem in using unit values to construct cost of living indices is that they are often positively correlated with the level of living, reflecting the use of better quality products by richer groups. By constructing unit values only for the bottom quantiles in different regions (as determined by the bottom $40 \%$ of the national sample), we mitigate the problem of standard-of-living-related quality variation. The second reason is that since the spatial price indices are to be used for poverty analysis, we would like the quantity weights for different expenditure categories to reflect the expenditure pattern of the poor rather than the whole population.

In estimating spatial price differences for non-food items using Engel functions, we broadly follow the approach discussed in Ravallion and Bidani (1994), and Ravallion (1994). We first define a food poverty line, denoted $z_{F}^{*}$, as the minimum level of per capita food expenditure required to meet some nutritional threshold. As discussed above (section 2.4), this is taken to be a per capita food expenditure of Rs. 200 per month at $1985-86$ national prices. The nominal food poverty line at $1990-91$ prices is derived using the temporal food price index (discussed in the following sub-section). 
For any survey year, given a $z_{F}^{*}$ defined at national prices, the food poverty line for region $R$ (denoted $z_{F}{ }^{R}$ ) is obtained as $z_{F}^{R}=P_{F}^{R} \cdot z_{F}{ }^{*}$. Next, we define basic non-food expenditure for region $R$ (denoted $z_{N}{ }^{\circledR}$ ) as the typical non-food expenditure (per capita) of a household in region $R$ whose total expenditure (per capita) is just equal to the food poverty line. The poverty line for region $R, z^{R}$, is then obtained as the sum of $z_{F}^{R}$ and $z_{N}{ }^{R}$. Basic non-food expenditure is determined by estimating a region-specific food-share equation, as below.

$$
w_{F i}^{R}=\alpha_{0}^{R}+\alpha_{1}^{R} h_{i}^{R}+\alpha_{2}^{R} c_{i}^{R}+\beta^{R} \ln \left(x_{i}^{R} / z_{F}^{R}\right)+\epsilon_{i}^{R}
$$

where $x_{i}^{R}$ is per capita (total) expenditure of household $i$ in region $R, w_{F i}^{R}$ is the share of food in the household's expenditure, $h_{i}^{R}$ is household size and $c_{i}^{R}$ is the number of children in the household under 10 years of age. 5

On writing

$$
\alpha^{R}=\alpha_{0}^{R}+\alpha_{1}^{R} \bar{h}^{R}+\alpha_{2}^{R} \bar{c}^{R}
$$

we can interpret the parameter $\alpha^{R}$ (evaluated at regional mean values) as the typical food share of a household in region $R$ whose total expenditure is just equal to the food poverty line. The poverty line for region $R$ can then be written

$$
z^{R}=z_{F}^{R}\left(2-\alpha^{R}\right)
$$

A national poverty line $z^{*}$ can be derived analogously. Hence, the spatial cost-of-living index for region $R$ relative to the nation as a whole can be derived

$$
P^{R}=z^{R} / z^{*}=P_{F}^{R}\left(2-\alpha^{R}\right) /\left(2-\alpha^{*}\right)
$$

There is of course no a priori reason why the national poverty line thus evaluated should coincide with the

\footnotetext{
${ }^{5}$ The parameter estimates for the food Engel functions for 1985-86 and 1990-91 are available not shown here but from the authors upon request.
} 
population-weighted average of regional poverty lines; however, with our data they virtually do, both for 1985-86 and 1990-91. ${ }^{6}$

\subsection{The temporal price index}

The methodology for constructing an index of change in the cost of living between the two survey dates is analogous to that for the spatial index. We will first define a temporal food price index between 1985-86 and 1990-91; this is defined in terms of national prices. Generalizing equation (1) above, we can write a Fisher's type food price index as

$$
P_{F}^{90 / 85}=\sqrt{\sum_{j} w_{j}^{* 85}\left(p_{j}^{* 90} / p_{j}^{* 85}\right) \cdot \sum_{j} w_{j}^{* 90}\left(p_{j}^{* 90} / p_{j}^{* 85}\right)}
$$

where for the respective years $p_{j}{ }^{* \prime} s$ are national unit values, and $w_{j}$ 's are the expenditure shares of food categories for the national reference group of households.

This food price index is estimated to be 193.5 with the base for $1985-86$ as 100 . (The Laspeyres and Paasche indices turn out to be very similar, 192.3 and 194.8 respectively). We use this to derive the reference (national) food poverty line at $1990-91$ prices, which comes to a nominal per capita food expenditure of Rs. 387. Combined with the spatial food price indices for 1990-91, the regional 1990-91 food poverty lines are thus generated, which in turn are used in the estimation of Engel functions (equation (2)) for 1990-91. The general poverty lines for 1990-91, regional and national, are derived as before using equation (3) above. Finally, the general price index between $1985-86$ and $1990-91$ is derived as the ratio of the 1990-91 national poverty line to the $1985-86$ national poverty line. This is estimated at 194.7. The complete set of spatial and temporal price indices, and the corresponding poverty lines are shown in Table 1.

Our estimates may be compared with the only temporal consumer price index that is available for Sri Lanka, viz., the Colombo Consumer Price Index (CPI). The latter can be compared with the estimates

6 The directly estimated national poverty lines for 1985-86 and 1990-91 were given by a per capita monthly expenditure of Rs. 242.06 and Rs. 471.20 , while the population-weighted averages of regional poverty lines turned out to be Rs. 242.34 and Rs. 471.54 respectively. 
for the urban sector of the Western region which includes Colombo (as well as the urban areas of Gampaha and Kalutara districts). The food CPI for Colombo for June-August 1990 with June-August 1985 as the base is 184.5 (DCS 1989, 1992). This compares with 194.4 as our estimate of the food price index for the urban Western region over the same period (Table 1). Similarly, the general price indices from the two sources are 180.7 and 196.0. While our estimates of the price increase over this period are higher, the difference is not large.

\section{$4 \quad$ Poverty during 1985-86 and 1990-91}

\subsection{Poverty in 1990-91}

The mean per capita consumption expenditure in Sri Lanka during 1990-91 was just below Rs 800 per capita per month, or about $70 \%$ above our reference poverty line (Table 2 ). By this reference poverty line, about 22.4 per cent of the Sri Lankan population, or about 3.8 million persons, are deemed to be poor in $1990-91 .^{7}$ Using a more generous (20\% higher) poverty line, the fraction deemed poor rises to 35.3 per cent, and the number of poor to about 6 million. (This indicates an elasticity of the headcount index with respect to the poverty line of over 2.8 .) The poverty gap indices for the two poverty lines are 4.8 and 8.8 per cent, implying an average poverty deficit of the poor (the proportionate shortfall of their average consumption from the poverty line) of 22 and 25 per cent respectively for the lower and higher poverty lines (see Table 3).

The incidence of poverty, as measured by the headcount index for the reference poverty line, is the greatest in the rural sector ( 24.4 per cent), followed by the urban sector ( 18.3 per cent), and is the least in the estate sector (12.6 per cent). Other poverty measures show a similar pattern. For this lower poverty line, the observed differences in poverty across sectors are statistically significant. The ranking of the three sectors remains unchanged for the higher poverty line, although the urban sector headcount index is no longer significantly higher than that in the estate sector. For still higher poverty lines, it cannot be claimed

7 This is using an estimated total Sri Lankan population of about 17 million for 1990-91. The estimated population of the regions covered by the two surveys is about 14 million, and thus for this region, the number in poverty (by the lower poverty line) is estimated at about 3.1 million. 
that urban poverty is higher than estate sector poverty even by the other poverty measures. The ranking of the rural and urban sectors however remains unchanged over different poverty measures and the two poverty lines. The sectoral poverty rankings depend both on differences in mean per capita consumption and relative inequalities within sectors. A comparison of the sectoral Lorenz curves shows that the urban sector Lorenz dominates the rural sector, which in turn dominates the estate sector Lorenz curve. Thus, regardless of the measure used, inequality is lowest in the estate sector and the highest in the urban sector, with the rural sector occupying an intermediate position.

The estimates show that poverty in Sri Lanka is predominantly a rural phenomenon; the rural sector accounts for about four-fifths of national poverty, which is higher than its share in the national population. The shares of the rural, urban and estate sectors in the total number of the poor (by the reference poverty line) are 79, 17 and 4 per cent respectively; this compares with their respective population shares of 72 , 21 and 7 per cent. The relative contributions of these sectors to national poverty are largely invariant over different poverty measures and poverty lines.

\subsection{Change between $1985-86$ and $1990-91$}

Our estimates indicate a statistically significant ${ }^{8}$ decline in absolute poverty over the two surveys (Table 3). For the headcount index using the reference poverty line, a decline of about $18 \%$ is indicated, from 27.3 per cent of the population in 1985-86 to 22.4 per cent in 1990-91. The decline in the absolute number of the poor is of course more modest, by about 12 per cent from 4.3 to 3.8 million. The decline in the poverty gap and the squared poverty gap measures is even greater (by about 26 and $30 \%$

8 The standard errors of poverty measures are based on the formulae in Kakwani (1990). These should be considered approximations of true standard errors since they are not appropriately weighted for differences in household size and sampling rates across households. Differences in poverty between states A and B can be tested using the test statistic

where

$$
t=\left(P_{A}-P_{B}\right) / \text { s.e. }\left(P_{A}-P_{B}\right)
$$

$$
\left[\text { s.e. }\left(P_{A}-P_{B}\right)\right]^{2}=\operatorname{var}\left(P_{A}-P_{B}\right)=\operatorname{var}\left(P_{A}\right)+\operatorname{var}\left(P_{B}\right)
$$

and s.e. () and var () denote the standard errors and variances of the poverty measures. This statistic is asymptotically distributed as standard normal. 
respectively), indicating a significant decline in both the depth and severity of poverty. In particular, the greater percentage fall in the poverty gap index relative to the headcount index implies a decline in the average poverty deficit of the poor. The percentage decline in the poverty measures is found to be lower for the higher poverty line; for this higher line, the headcount, poverty gap and squared poverty gap indices declined by about 13,21 and 26 per cent respectively. This suggests that ultra poverty declined somewhat more sharply than poverty in general.

The time pattern of change in poverty is very uneven at the sectoral level. For the reference (lower) poverty line, the incidence of poverty declined substantially in the rural sector by $23 \%$, more moderately in the estate sector by $12 \%$, but in the urban sector it increased by $11 \%$. The pattern is similar for the higher line, but it changes somewhat for the other poverty measures. For example, the estate sector indicates the greatest decline in the severity of poverty (by over 50 per cent); this is largely achieved by way of a significant reduction in intra-sectoral inequality (see Ginis for 1985-86 and 1990-91 in Table 2). The contribution of different sectors to the decline in aggregate poverty is discussed further below.

\subsection{Dominance analysis}

Robustness of ordinal poverty comparisons can be analyzed more rigorously using the stochastic dominance approach (Atkinson 1987), whereby robustness of comparisons is examined with respect to a broad class of poverty measures and a range of poverty lines. Specifically, we will look for restricted first order dominance (FOD) over the range 50-300 per cent of the reference poverty line. This is quite a wide range; the cumulative proportion of the national population at the two end points of this range is about 2 and 92 per cent respectively? Restricted FOD has the following implication: if distribution $A$ has restricted FOD over distribution $B$, then poverty in $A$ is unambiguously higher than poverty in $B$ for a broad class of poverty measures and for all poverty lines up to the maximum poverty line over which restricted FOD

\footnotetext{
9 The notion of restricted FOD bounded below by a minimum poverty line can be given both a normative or a statistical justification. For further discussion of restricted dominance, see Howes (1993).
} 
is observed. The necessary and sufficient condition for restricted FOD of A over B is that (i) the cumulative distribution function (CDF) of $\mathrm{A}$ lies above that of $\mathrm{B}$ over some range defined by a minimum and a maximum poverty line, and (ii) at the minimum poverty line the poverty gap of $\mathrm{A}$ is no less than poverty gap of B. ${ }^{10}$

Figure 1 plots the CDFs for the rural, urban and estate sectors for 1990-91. The main results are readily summarized. The rural CDF dominates the urban CDF over the entire range from 50 to 300 per cent of the poverty line, implying unambiguously higher poverty in rural areas. The rural CDF also dominates the estate sector CDF up to about 175 per cent of the poverty line, implying higher rural poverty for all poverty lines up to that limit. The urban and estate sector CDFs intersect at about 120 per cent of the reference poverty line, or at our higher poverty line. Thus, the estate sector has lower poverty than the urban sector for all poverty lines up to our higher poverty line, but beyond that we are unable to unambiguously rank the two sectors. The sectoral CDFs for 1985-86 are indicative of similar results except that it is no longer possible to infer any restricted dominance between the urban and the estate sectors.

Figure 2 addresses temporal comparisons. We plot the national CDFs for 1985-86 and 1990-91, which indicate a decline in poverty over this period for all poverty lines up to over 200 per cent of the reference poverty line. Similarly, a decline in rural poverty is indicated up to about 225 per cent of the poverty line (the sectoral graphs not included for lack of space). The urban sector CDF for 1990-91, however, lies above 1985-86 CDF throughout the range, though the curves are closer together and they are virtually indistinguishable at about 80 per cent and 200 per cent of the poverty line. This is close to restricted FOD implying an increase in urban poverty. But even if there is an element of doubt about restricted FOD, restricted second order dominance, which involves a comparison of the areas under the CDFs, is almost certainly assured. Restricted SOD here implies an increase in urban poverty for all

\footnotetext{
10 In the following discussion, we ignore the second sub-condition. In all cases where restricted dominance holds, this condition is always satisfied, if not at the minimum of 50 per cent of the poverty line, then certainly for a value between $50-60$ per cent. For these latter cases, restricted dominance can be appropriately considered to apply for a slightly higher lower bound.
} 
poverty measures that are non-decreasing in regressive transfers ${ }^{11}$, and for all poverty lines within the 50 300 per cent range.

For the estate sector too, we get only limited dominance results. Restricted FOD implying a fall in estate sector poverty holds only up to about the reference poverty line. In Figure 3, we look for restricted SOD for a clearer resolution of the comparison over time. Restricted SOD dominance, however, does not significantly enlarge the region of a clear poverty ranking. Only up to about 105 per cent of the reference poverty line can poverty in the estate sector in 1990-91 be considered lower than that in 1985-86.

\subsection{Sectoral decomposition of changes in poverty}

It was noted earlier that the changes in poverty rates have been quite diverse across the three sectors. We now look at the sectoral contributions to the observed change in national poverty. The change in national poverty over the two dates, $1985-86$ and $1990-91$, is readily decomposed as

$$
\begin{aligned}
P^{90}-P^{85}=w_{r}^{85}\left(P_{r}^{90}-P_{r}^{85}\right) & +w_{i}^{85}\left(P_{\mu}^{90}-P_{i}^{85}\right)+w_{e}^{85}\left(P_{e}^{90}-P_{e}^{85}\right)+\sum_{i}^{r, \mu, e}\left(w_{i}^{90}-w_{i}^{85}\right) P_{i}^{85} \\
& +\sum_{i}^{r, u, e}\left(w_{i}^{90}-w_{i}^{85}\right)\left(P_{i}^{90}-P_{i}^{85}\right)
\end{aligned}
$$

where $P_{i}^{t}$ is the poverty measure for sector $i$ in year $t$, and $w_{j}^{t}$ is the population share of sector $i$ in year $t$, for $i=$ rural, urban, estate. The first three terms in the above equation relate to the intra-sectoral effects, or the contribution of within-sector change in poverty to the overall change in national poverty. The third term is due to intersectoral population shifts, and measures how much national poverty would have changed solely on account of population shifts across sectors if poverty within sectors had remained unchanged. The last is a covariance term accounting for the interaction of the intra- and inter-sectoral effects.

The results of this decomposition for the two poverty lines are given in Table 4. Over this period,

"This rules out the headcount index and Sen's poverty measures, but does include the poverty gap and the squared poverty gap measures. 
there is very little change in the population shares of the three sectors (see Table 2). Thus, the components for inter-sectoral population shift and the interaction term turn out to be negligibly small. The main result of this decomposition is that the decline in national poverty between 1985-86 and 1990-91 is entirely due to the decline in rural poverty. Urban poverty in fact increased, thus contrituting to a small increase in national poverty (of the order of 7-8 per cent of the total change in national poverty). The estate sector accounted for 2-7 per cent of the decline in national poverty; its low share largely reflects its small weight in total population. These results are quite uniform across poverty measures and poverty lines.

\subsection{Growth and redistribution components of changes in poverty}

We can also decompose the observed changes in sectoral poverty into growth and redistribution components, following Datt and Ravallion (1992). The growth component is defined as the change in poverty due to a change in mean consumption, while holding the Lorenz curve constant. The redistribution component is defined as the change in poverty due to a change in the Lorenz curve, while holding mean consumption constant. This leads to the following decomposition:

$$
\begin{aligned}
& P\left(\mu_{j}^{90}, \pi_{j}^{90}\right)-P\left(\mu_{j}^{85}, \pi_{j}^{85}\right)=\left[P\left(\mu_{j}^{90}, \pi_{j}^{85}\right)-P\left(\mu_{j}^{85}, \pi_{j}^{85}\right)\right]+\left[P\left(\mu_{j}^{85}, \pi_{j}^{90}\right)-P\left(\mu_{j}^{85}, \pi_{j}^{85}\right)\right]+\text { Residual } \\
& \text { Change in poverty }=\text { Growth component }+ \text { Redistribution component }+ \text { Residual }
\end{aligned}
$$

where $\mu_{j}^{t}$ and $\pi_{j}^{t}$ are the mean consumption and Lorenz curve for sector $j$ in year $t$.

The results of this decomposition (given in Table 5) show an interesting contrast across the three sectors. First, for the rural sector, the observed decline in rural poverty is roughly evenly split between the growth and the redistribution components, with a somewhat higher contritution of the latter. For different combinations of poverty measures and poverty lines, growth in mean consumption accounts for 46-51 per cent of the overall decline in rural poverty, while 50-65 per cent is attributable to favorable redistribution.

In the urban sector, mean consumption declined in real terms, and thus it would be expected that the growth component contributed to an increase in poverty. The decomposition results show that the 
observed increase in urban poverty is fully accounted for by the decline in mean consumption. This is generally true for all poverty measures and both poverty lines, though the impact on the headcount index is mitigated by some favorable redistribution. This mitigating effect is not carried through to the other poverty measures, particularly the (distribution sensitive) squared poverty gap measure, which suggests that the reduction in relative inequalities is limited to the region around the poverty line.

The results for the estate sector are sharply different. Here, we find a relatively small decline in the headcount index, a more substantial decline in the poverty gap index, and quite a hefty decline in the squared poverty gap index. This decline occurred despite a fall in real mean consumption in this sector, which also implies that the decline in poverty is entirely on account of favorable redistribution, as borne out in Table 5. The favorable redistribution is consistent with the observed increase in real wages in the estate sector, as indicated by the following data on real wages from the DCS (1991):

Index number of real wages in $1990^{12}$

(Base $1985=100$ )
Tea and rubber

estate workers

111.2
Unskilled male workers in government employment in Colombo

105.9

which indicates a relatively larger increase in the real wages of tea and rubber estate workers.

Overall, the decompositions thus present a picture of favorable redistribution contributing significantly to poverty reduction, especially in the rural and estate sectors. However, a significant contribution of the growth component to poverty reduction was limited to the rural sector only.

\section{$5 \quad$ A profile of poverty}

\subsection{A regional poverty profile}

For the purpose of constructing a regional poverty profile we have merged the estate sector with the rural sector. This is done for two reasons: first, the estate sector is insignificant or non-existent in some regions, and second, the sample size for the estate sector is relatively small in the two surveys. Regional

12 These are the indices for the minimum (statutory) wage rates rather than the actual wage rates. However, the minimum wage laws are likely to be observed in the estate and the government employment sectors considered here. 
poverty estimates for 1990-91 for the reference poverty line are presented in Table 6. (Regional poverty estimates for 1985-86 are not presented here but are available from the authors.) The following observations can be made on the main results.

(i) The results for 1990-91 indicate only limited regional variation in poverty. Only in the Western region are the poverty levels found to be significantly lower than the other regions. Poverty estimates for the other four regions are quite similar. Limited variation in regional poverty levels carries the implication that the contribution of different regions to aggregate (national) poverty is roughly proportional to their population shares.

(ii) Regional variations in poverty were distinctly more pronounced in 1985-86; over time there has been a move toward convergence. Thus, in 1985-86 the Southern and South Central regions had significantly greater poverty than the Central and the North Western \& North Central regions, which in turn were significantly poorer than the Western region. Between 1985-86 and 1990-91, while poverty in the Western region increased a little (mainly in the urban sector), it declined significantly in the Southern and the South Central regions (mainly in the rural sector). ${ }^{13}$ On the whole, this has led to a considerable dampening of regional disparities in poverty.

(iii) Within a region, rural poverty is generally higher than urban poverty. Over the two survey periods, there has also been a considerable narrowing of rural-urban poverty differentials within regions. This observation generalizes to the regions what has already been noted at the national level.

\subsection{Poverty by sector of employment}

In constructing poverty profiles by sector of employment, it is commonplace to classify households according to the principal occupation of the head of the household. This practice neglects occupational diversity within the household (not to mention multiple occupations for the individuals themselves). We construct an occupational poverty profile which does not overlook this diversity. We first assign all working individuals to their reported sectors of employment. Poverty measures for each sector of

13 There was also a moderate decline in poverty in the other two regions. 
employment are then computed assuming each individual's consumption is given by the per capita consumption of the household to which (s)he belongs (which is consistent with the standard of living indicator we have been using), and each individual's weight given by the ratio of household size to the number of working individuals in the household. Table 7 presents the poverty profile by the sector of employment for the reference poverty line, while Table 8 shows the changes in poverty by employment sector and the contribution of different sectors to the total change in poverty between 1985-86 and 1990-91. The main features of the results in Tables 7 and 8 are as below. ${ }^{14}$

(i) In 1990-91, the sectors reporting levels of poverty above the national average were: agriculture, forestry, fishing; mining and quarrying ${ }^{\mathrm{ds}}$; construction; and the unclassified group comprising of those whose industry of employment is not adequately defined. The highest levels of poverty are reported for the unclassified group which is likely to have a high proportion of casual laborers in irregular employment. Poverty rates for the manufacturing, electricity, gas and water sector are about the same as the national average. The remaining sectors have lower poverty, with the lowest levels observed for transport, storage and communications sector. The pattern is similar for $1985-86$.

(ii) In terms of changes over time, the largest decline in poverty (by all poverty measures) occurred in the agriculture, forestry and fishing sector (Table 8). Substantial declines in poverty rates were also witnessed by the manufacturing, electricity, gas and water sector, the mining and quarrying sector and the unclassified group. There was a significant increase in poverty in the trade, hotels, finance, insurance, real estate sector, and the commercial and social services sector. In the former sector, while mean per capita consumption remained virtually unchanged (in real terms) between 1985-86 and 1990-91, relative inequalities increased; this is reflected in larger increases in the poverty gap and the squared poverty gap indices than in the headcount index. In contrast, both mean consumption and relative inequalities declined in the commercial and social services sector, which seems consistent with the large increase in the

\footnotetext{
14 The estimates are based on $93 \%$ of the sample households for 1990-91 and $92 \%$ of sample households for 1985-86; the remaining households were excluded due to missing information on the sector of employment.

15 The estimates for this sector have large standard errors reflecting its small sample size; these should be suitably interpreted.
} 
headcount index, but relatively smaller increases in the other poverty measures reflecting the depth and severity of poverty. The construction sector also witnessed a moderate decline in poverty.

(iii) The agriculture, forestry and fishing sector alone contributed more than four-fifths of the overall decline in national poverty between 1985-86 and 1990-91. This holds for all poverty measures, and reflects both the substantial decline in poverty in this sector as well as the large share of agriculture in overall employment. This is consistent with the sectoral decomposition results discussed earlier. (The decompositions in Table 8 use the same methodology as introduced earlier in section 4.4.) The manufacturing sector (including electricity, gas and water) contributed between 11-16 per cent and the unclassified group between $7-13$ per cent to the overall decline in aggregate poverty. The contribution of the trade and commercial and social services sectors is negative (though not large in absolute terms) insofar as poverty increased within those sectors.

\subsection{Female headship and poverty}

About 20 per cent of the households in Sri Lanka are female-headed, and they account for about 17 per cent of the total population. Are female-headed households poorer? Estimates of poverty (for the reference poverty line) by the gender of the head of the household for 1990-91 and 1985-86 are given in Table 9. For 1985-86, for the island as a whole we find that the incidence of poverty (i.e., the headcount indices) for female headed households is not significantly different to that for male-headed households. However, by other poverty measures, female-headed households are indicated to be significantly poorer; although the differences, while significant statistically, are not large. The same result also applies to the rural sector. ${ }^{16}$ However, in urban areas female headship is more clearly associated with significantly higher levels of poverty.

Between 1985-86 and 1990-91, poverty in the urban sector increased both amongst male and female headed households, and it decreased for both in the rural sector. The relative positions of male and female headed households in 1990-91 thus turn out to be similar to those for 1985-86. While poverty

16 The rural sector includes the estate sector too. 
differences between the two groups remain insignificant in the rural sector and the island as a whole, urban female headed households are observed to be poorer than their male-headed counterparts. Overall, the evidence thus suggests that uncontrolled for other household attributes (a) the association of female headship with higher poverty is limited to the urban areas only, and (b) fenale headship seems to matter little for changes in poverty over time, which appear to be largely independent of the gender of the household head.

\subsection{Poverty and household size and composition}

The results on household size and composition by level of poverty for 1990-91 are presented in Table 10. The overall average household size for Sri Lanka was just under 5 in 1990-91. Not surprisingly, household size declines as we move from the poorest to the richest strata in the population. Thus, the average size of a household in the poorest group (below 50 per cent of the poverty line) is about 7 , it is about 6 for the ultra poor (below the reference poverty line), around 4.5 for the non-poor, and 3.6 for the richest group (with per capita expenditure more than four times the reference poverty line). This positive relation between household size and poverty is a very common finding for developing countries. The positive relationship is of course accentuated by the use of per capita consumption as the standard of living indicator, which does not allow for economies of scale in consumption. However, the results suggest that such economies would have to be substantial to reverse the conclusion that poorer households tend to be relatively larger in size. ${ }^{17}$

The main result with regard to household composition has to do with the higher dependency ratio for the relatively poor. Children under age 10 account for about one-fourth of all household members amongst the ultra poor; this increases to about two-fifths if we look at the under 15 age group. By contrast, the respective proportions amongst the non-poor are about 17 and 28 per cent. On the other hand, the

17 Obtaining credible estimates of economies of scale in consumption is a empirically difficult. The common approach is based on the estimation of demand functions and the derived cost functions. A key problem relates to the under-identification of the cost functions from observable demand behavior, and hence the difficulty of separating out the economies of scale from other welfare effects of household size (see Deaton, 1995, and Lanjouw and Ravallion, 1995). 
share of the age group 15-60 increases from under 55 per cent for the ultra poor to over 62 per cent for the non-poor. The share of the old (over 60 years) also increases from about 6 per cent for the poorest group to about 14 per cent for the richest group; this is suggestive of longer life expectancy for the relatively rich.

\subsection{Poverty and education}

Sri Lanka is well-known for its record on progress in literacy and basic education. Using the HIES data, we estimate that the overall literacy rate (defined as the percentage of literates in the population above 10 years of age) in 1990-91 was about 87 per cent, 90 per cent for males and 84 per cent for females. The literacy rates do vary inversely with the level of poverty, but the variation is not large (Table 11). Thus, amongst the ultra poor (those below the reference poverty line) the male and female literacy rates were 84 and 80 per cent; among the poor (those below the $20 \%$ higher poverty line) these were 86 and 81 per cent; and amongst the non-poor these were 92 and 85 per cent respectively. Over the entire range, the male literacy rate increases from about 81 per cent for the poorest group (below 50 per cent of the poverty line) to near universal literacy (about 97 per cent) for the richest (with per capita expenditure more than four times the poverty line). The increase is quite rapid over the bottom end of the distribution, reaching a level of 91 per cent by $120-150$ per cent of the poverty line. The female literacy rate also increases from about 80 to 94 per cent from the poorest to the richest groups, though for females it increases relatively slowly (to about 84 per cent) up to a per capita expenditure of twice the poverty line.

The pattern is similar for the average years of schooling (last two columns of Table 11). The overall average is about 7 years of schooling per person 10 years or older, the average for males being slightly higher ( 7.2 years) than for females (6.9 years). For both males and females, this average ranges from about 5 years of schooling for the poorest group to the about 10 years for the richest.

We also looked at sectoral variations in this pattern (Table 12). Both the literacy rates and the average years of schooling are lower in the rural (including estate) sector than in the urban sector. Thus, for example, the female literacy rate amongst the ultra poor population in rural areas is about 79 per cent 
against 84 per cent in urban areas; the sectoral disparity is even higher amongst the non-poor. A similar pattern obtains for male literacy rates as well as for the male and female average years of schooling. The results also confirm at the sectoral level both the gender disparities in education and the inverse relationshp between poverty and the level of education already noted at the national level.

\subsection{Labor force participation, employment, unemployment and poverty}

Table 13 gives the 1990-91 distribution of the population aged above 10 years by employment status (employed, unemployed or outside the labor force) and by percentage of the poverty line. The following observations can be made on the results in this Table. ${ }^{18}$

(i) Overall, in 1990-91 nearly half of those above 10 years of age participated in the labor force; the labor force participation rate (LFPR) is defined as the percentage of those available for work (the employed plus the unemployed) in total population above 10 years of age. ${ }^{19}$

(ii) The poorer groups have somewhat lower labor force participation rates. The latter range from about 46 per cent for the ultra poor to about 50 per cent for the non-poor. It may appear that this is simply on account of the ultra poor having a higher share of the very young (10-15 years) and the aged (above 60 years) amongst those above 10 years of age. There is only a limited sign of this; the combined share of these two groups (in those older than 10 years) was 27.7 per cent for the ultra poor, 27.7 per cent for the poor, and 25.3 for the non-poor.

(iii) The rest of the explanation is to be found in the the age-specific LFPRs (Table 14). For the age group 15-60, the LFPRs amongst the ultra poor and the poor are somewhat lower relative to the non-poor. The LFPRs for those above 60 years are also found to be lower amongst the poor relative to the non-poor. The Table also shows that on the whole only about 4 per cent of the 10-15 year olds participate in the labor force, this rate being slightly higher for the ultra poor at 4.7 per cent, and somewhat

\footnotetext{
18 For Table 13, the poorest group is defined as 0-80 per cent of the reference poverty line. The group 0-50 is not separately identified because it has relatively few observations.

19 We use 10 years (instead of 15) as the age threshold for defining labor force participation in view of the fact many of those in the 10-15 age group do participate actively in the labor force, particularly in the rural sector.
} 
lower for the non-poor at 3.6 per cent. In sum, while the relatively poor tend to have lower LFPRs, the differences are not large, and the observed differences are traceable to variations in both the age-specific LFPRs as well as the age-composition of poor and non-poor households.

(iv) As may be expected, labor force participation rates differ greatly by gender. (Tabulations of labor force characteristics disaggregated by gender though not presented here are available from the authors.) In 1990-91, while more than two-thirds of males above 10 years of age participated in the labor force, the proportion for females in the same age group was less than one-third. For both men and women, labor force participation increases with per capita expenditure, and at comparable rates.

(v) The average unemployment rate (defined as the ratio of the unemployed to those participating in the labor force) for $1990-91$ was around 16 per cent. ${ }^{20}$ The results also indicate a strong positive relationship between unemployment and poverty. The unemployment rate declined from about 25 per cent for the poorest group (below 80 per cent of the poverty line) to 5.5 per cent for the richest (above 400 per cent of the poverty line); the average for the poor is around 20 per cent.

(vi) The unemployment rates are significantly higher for women than for men, 24 per cent as against 13 per cent on average. They are also significantly higher for poor women (29\%) than non-poor women $(21 \%)$, and for poor men (17\%) than for non-poor men (11\%).

\subsection{Poverty and occupational distribution}

We now look at the occupational distribution of those who are employed by percentage of the poverty line. To avoid having to work with cells with only a few observations, we distinguish only 7 occupation-employment categories, as follows. First, we identify three economic sectors: agriculture, urban non-agriculture and rural non-agriculture. Then, each of these three categories is split into two groups, for employees and the self-employed. Finally, we have an unclassified category for those whose

20 This may seem high, but is not untypical for the definition of unemployment used in Sri Lanka; the average unemployment rate for 1985-86 was about 14 per cent. The definition of unemployment is in terms of being available for work but not employed for most of the reference period. The reference period is the last 12 months. More importantly, the unemployed do not have to be seeking employment, but are defined as those "ready to work when an opportunity is given" (DCS, 1987, p. 12). 
occupation or industry of employment is not adequately defined. Table 15 gives the 1990-91 distribution of the employed into these 7 categories by per capita expendiure groups. Since these categories are used to classify individuals rather than heads of household, the results in the Table fully accommodate occupational diversity within the household. Our main observations are as below.

(i) For the poor, agriculture accounts for about 47 per cent of those employed; the share of agriculture is around 44 per cent for the ultra poor, and around 42 per cent for the non-poor. These may be compared with the overall share of employment in agriculture of about 43 per cent. While this does not suggest any significant over representation of the poor in the agricultural sector, two further points may be noted. First, the share of agriculture starts declining rapidly beyond 200 per cent of the lower poverty line. Thus, between 200-250 per cent of the poverty line, it is 36 per cent, and it declines all the way to 16 per cent for the group above 400 per cent of the poverty line. Second, the share of agricultural employees declines rather more sharply between the poor and the non-poor, from 24 to 18 per cent. In contrast, the share of the self-employed in agriculture is marginally higher for the non-poor than the poor. Amongst the self-employed in agriculture itself there is a clear inverse relationship between the amount of land owned and poverty (Table 16).

(ii) Rural non-agriculture accounts for about 31 per cent of the employed amongst the poor, and about 37 per cent amongst the non-poor. Most of this difference is on account of the difference in the share of employees in rural non-agriculture, which is 22 per cent amongst the poor and 26 per cent amongst the non-poor. The overall share of rural non-agricultural employment is about 35 per cent.

(iii) Amongst the poor, urban non-agriculture accounts for a relatively small proportion, 12 per cent, of those employed. Its share amongst the non-poor is about 19 per cent; this increase up to 45 per cent for the highest per capita expenditure group (above four times the reference poverty line). The shares of both the employees and the self-employed in this sector generally increase with the per capita expenditure groups.

(iv) Consistent with the earlier discussion in section 5.2, the share of the unclassified group (which includes casual laborers in informal activities) declines steadily with per capita expenditure. 


\subsection{Expenditure pattern by level of poverty}

The expenditure pattern by the level of poverty for 1990-91 is shown in Table 17 for the food group and Table 18 for the non-food group. Unlike the definitions adopted in the construction of spatial and temporal price indices (section 3), the "food" and "non-food" groups have their usual meanings. ${ }^{21}$ It is also worth reiterating that our definition of total consumption expenditure excludes expenditure on durables, which may partially account for the generally high food shares in Table 17 . The results in the two Tables are largely self-explanatory. We can limit the discussion to some brief remarks.

Consistent with Engel's law, food share declines steadily from about 80 per cent for the poorest group to about 40 per cent for the richest. The poor devote more than three-quarters of their total budget to food, with rice being the single most important consumption item accounting for about one-fourth of their total expenditure. Though food looms large in the poor's budget, items such as pulses, milk and dairy products do not figure significantly in their consumption. Within the non-food group, fuel and light, housing, clothing are the relatively important items for the poor. Housing can be clearly identified as a luxury; its budget share rises steadily for higher per capita expenditure groups. Health and personal care accounts for under 3 per cent of total expenditure of the poor, and education accounts for little over 1 per cent. In part, these low shares a reflection of poverty, but the budget shares of these items also rise fairly slowly with per capita expenditure. An important part of the explanation is almost certainly to be found in public expenditures on health and education.

\section{Targeting and growth}

\subsection{Targeting implications of the poverty profile}

A poverty profile offers valuable guidance on how poverty reduction efforts may be targeted and prioritized. From the different dimensions of the poverty profile presented above, one can draw out the implications for indicator targeting by using two targeting indices. The indices provide a measure of how

\footnotetext{
21 In terms of the items listed in Annex 1, the food group here consists of items 1-36 and 39, while non-food consists of items 37,38 and $40-52$.
} 
much impact on aggregate (national) poverty can be expected from an incremental transfer targeted to groups distinguished by a particular household indicator or characteristic. The two indices differ in the assumptions made about how the transfers are distributed within groups. Two benchmark cases here correspond to the additive (or uniform) and multiplicative (or proportional) transfers. Additive transfers are those for which the amount transferred is the same for all persons within the group; such transfers are progressive insofar as the same absolute transfer translates into a higher proportion of income or expenditure for the relatively poor. With multiplicative transfers, the amount transferred is proportional to the recipient's income or expenditure; these transfers are distributionally neutral. It can be shown that to minimize $P_{\alpha}$, for $\alpha>0$, transfers to groups should be targeted in the order of the observed values of:

$P_{\alpha \cdot l j}$ for additive transfers, and

$\left(P_{a-l j}-P_{a j}\right) / \mu_{j}$ for multiplicative transfers, where $\mu_{j}$ is the mean per capita consumption for group $j .{ }^{22}$ These targeting indices are readily calculated from the results on mean consumption and poverty measures discussed above. In the following, we present targeting indices for $\alpha=2$, which assumes that the policy objective accords a greater weight to reducing poverty for the relatively poorer. We normalize these indices by the national values of the same index, and express them as percentages. Thus, for instance, for additive transfers the relative targeting index is given by the poverty gap measure for group $j$ as a percentage of the national poverty gap.

These indices are shown in Table 19. Groups with relatively high values of both indices may be considered good candidates for targeting of resources towards then or for policies favoring them. These include: among the sectors, the rural sector; among the regions, the central and south central regions (particularly their rural sectors); among the employment sectors, mining and quarrying, construction, the "unclassified" sector, and agriculture; female-headed households; the Sri Lankan Moors, Malays, Burghers; agricultural households owning under 1 acre of land ${ }^{23}$; households headed by persons with no schooling; and rural households with unemployed heads of households.

22 The underlying theory of targeting can be found in Kanbur (1987); also see Datt and Ravallion (1993).

23 Also see Table 16 for related results on poverty and size of land owned by agricultural households. 


\subsection{Targeting performance of the Food Stamp Program}

Since the early 1980s, the Food Stamp Program has been a key component of the government's poverty alleviation strategy in Sri Lanka. The program is supposed to be income-tested, with the amount of food stamp receipts depending on the household's income, its size and composition. The 1990-91 HIES data, which include information on food stamp receipts, provide us with an opportunity to assess the targeting performance of the program.

In Figure 4, we use the 1990-91 HIES data to plot the share of food stamp receipts in total (pretransfer) household consumption expenditure against pre-transfer per capita expenditure expressed as a percentage of the reference poverty line. The Figure shows both the scatter points for the country as a whole, and also a cubic spline which smooths the data. It also shows a decreasing convex solid curve which represents the untargeted case of uniform transfers of the same gross budget; this simulates doling out the entire food stamps budget equally amongst all persons. The uniform per capita transfer turns out to be Rs. 12.74 per month at $1990-91$ prices. Expressed as a proportion of pre-transfer per capita expenditure, this yields the convex monotonically decreasing curve of Figure 4. Uniform transfers are progressive by definition, and they offer a convenient benchmark against which the targeting performance of the Food Stamps program may be assessed.

The figure should be interpreted with some caution; notice in particular scatter points lined at zero food stamp share. These are the non-recipients. However, from the graph we do not know the density (or thickness of the line) at the zero share, or the relative frequency of being a non-recipients. This is better reflected in the cubic spline which is pulled closer to the zero-share line for higher relative frequency of the non-recipients.

The graph in Figure 4 suggests reasonably good targeting performance of the Food Stamp program. The transfers implied by the program are progressive insofar as the share of food stamp receipts declines with the percentage of the poverty line. At around 50 per cent of the poverty line, this share is about 15 per cent of the recipients' (pre-transfer) consumption expenditure. It tapers off steadily all the way to the higher poverty line, and is not significantly different to zero beyond 150 per cent of the reference poverty 
line. The graph also suggests that roughly up to the reference poverty line the receipts from food stamps are more progressive than uniform transfers.

Figures 5 and 6 show corresponding graphs for the rural and the urban sectors. The estate sector is merged with the rural sector; the number of food stamp recipients in the estate sector is too small to maker more definite inferences about progressivity. The rural sector graph closely parallels the national graph, which is not surprising given that this sector accounts for the large bulk of the food stamp recipients and receipts. The program seems well-targeted within the rural sector; food stamp receipts are more progressive than uniform transfers approximately up to the higher poverty line. The graph for the urban sector also suggests an element of progressivity, though the number of recipients in this sector is rather small to infer definitively.

All figures (4 through 6) show that there are both many recipients of food stamps amongst the nonpoor and many non-recipients amongst the poor. While these targeting errors influence the program's relative cost-effectiveness in alleviating poverty, it is important to look at the entire distribution of transfer benefits. Figure 7 presents the cumulative distribution functions (CDF) of per capita consumption under three scenarios: (i) the actual CDF, or the CDF with food stamps, (ii) the CDF of pre-transfer consumption, or the CDF without food stamps, and (iii) the CDF with uniform transfers in lieu of the food stamps. The main result is readily stated. Although the three CDFs are close together (reflecting the relatively small size of the food stamps budget), the CDF with uniform transfers dominates (lies above) that with food stamps roughly up to the higher poverty line. Direct transfers from the food stamps program reduce poverty by more than would be possible under uniform transfers of the same gross budget for all poverty lines up to our higher poverty line. ${ }^{24}$

The above assessment of the Food Stamp program is nevertheless subject to some caveats. First, a reasonably good performance relative to uniform transfers does not imply that the potential for improved targeting has been exhausted. The significant errors of exclusion of the poor and inclusion of the non-poor

\footnotetext{
24 With poverty deficit curves (cumulatives of the CDFs), the point of intersection (of the two poverty deficit curves) would be pushed up further, implying restricted second-order dominance over bigger range of poverty lines.
} 
are indicative of some unexploited scope for better targeting. Second, our assessment has been limited to the direct (consumption) benefits of the Food Stamp program. There may be several second-round effects of the program. For example, Sahn and Alderman (1992) estimated that the Sri Lankan food subsidy led the recipient household members to curtail their market labor supply by 3-5 days per month. The existence of such induced effects can substantially modify an initial assessment of cost effectiveness based on direct transfer benefits only.

\subsection{Growth and implications for future poverty alleviation}

Table 20 presents some simulations on the impact of growth on future poverty alleviation. Five and ten-year projections of poverty are made for different rates of growth of real per capita consumption, assuming relative inequalities remain unchanged at the observed 1990-91 levels. The results are largely self-explanatory. For example, a $2 \%$ annual rate of growth of real consumption per capita would, by the turn of the century, reduce the proportion of the ultra-poor from 22 to 12 per cent; it would reduce the proportion of the poor from 35 to 21 per cent. This rate of growth, though not overly ambitious, is nonetheless much higher than the $0.4 \%$ annual growth in real mean consumption observed over the two

survey dates. The projections should however be interpreted with caution given the assumption of distribution neutrality. The expected gains in poverty alleviation could be greatly diminished (or enhanced) if growth were accompanied by unfavorable (favorable) redistribution.

\section{$7 \quad$ Summary and conclusion}

About 3.8 million persons, or about 22.4 per cent of the population, were deemed to be poor in Sri Lanka in 1990-91 (using a poverty line corresponding to a normative threshold of 2500 calories and 53 grams of proteins per adult male equivalent per day while also allowing for basic non-food expenditure). Poverty is observed to be the greatest in the rural sector, and the least in the estate sector, with the urban sector in the intermediate position. Overall, poverty in Sri Lanka is a predominantly rural phenomenon, with the rural sector accounting for nearly four-fifths of aggregate poverty; this proportion is largely 
invariant over different poverty measures and poverty lines. A little less than half of the poor depend on agriculture for their livelihood, while another 30 per cent depend on other rural non-agricultural activities. Between 1985-86 and 1990-91, there has been a modest decline in aggregate poverty, which is almost entirely attributable to the fall in rural poverty, although poverty in the estate sector also declined. Urban poverty appears to have increased over this period. Growth in rural mean consumption and favorable redistribution contributed roughly equally to the observed decline in rural poverty. In terms of the sector of employment, we find that agriculture, forestry and fishing accounted for about 80 per cent of the total decline in national poverty over this period.

Regional variations in poverty are found to be relatively limited; only in the Western districts of Colombo, Gampaha and Kalutara are poverty levels observed to be significantly below those in the rest of the country. There is also evidence of narrowing regional disparities in poverty between 1985-86 and 1990-91. Similarly, the evidence also indicates a narrowing of the rural-urban poverty differential. Female headship appears to be associated with greater poverty only in the urban sector; the association tends to disappear at the national level. Other aspects of the Sri Lankan poverty profile indicate that the relatively poorer households tend to have higher dependency ratios, lower rates of labor force participation, and significantly higher rates of unemployment. The poor also had lower average years of schooling and lower literacy rates, although differences in literacy rates between the poor and the non-poor are not large, and even the poor had literacy rates upwards of 80 per cent.

Our assessment of the targeting performance of the Food Stamp Program suggests that direct transfer benefits from the program are progressive. And they have a larger impact on poverty than would have been implied by uniform allocations of the same budget. Our simulations also indicate sizable potentiall gains in poverty reduction from future growth; for example, a modest 2 per cent annual growth in real per capita consumption over the 1990s, if unaccompanied by adverse redistribution, could cut poverty levels to about half their observed levels at the beginning of the decade. There can be no presumption however that such growth is easily accomplished. 


\section{References}

Atkinson, Anthony B. (1987). On the Measurement of Poverty. Econometrica, 55:749-64.

Anand, Sudhir and Christopher Harris (1985). Living Standards in Sri Lanka, 1973 - 1981/82: An Analysis of Consumer Finance Survey Data. World Bank, Washington D.C., mimeo.

Aturupane, Harsha, Paul Glewwe and Paul Isenman (1994). Poverty, Human Development and Growth: An Emerging Consensus. American Economic Review, 84:244-249.

Bhalla, Surjit (1988a). Is Sri Lanka an Exception? A Comparative Study of Living Standards. In T. N. Srinivasan and P. K. Bardhan (eds) Rural Poverty in South Asia, Oxford University Press, Delhi. (1988b). Sri Lanka's Achievements: Fact and Fancy. In T. N. Srinivasan and P. K. Bardhan (eds) Rural Poverty in South Asia, Oxford University Press, Delhi.

Bhalla, Surjit and Paul Glewwe (1985). Living Standards in Sri Lanka in the Seventies - Mirage and Reality. World Bank, Washington D.C., mimeo.

Bhalla, Surjit and Paul Glewwe (1986). Growth and Equity in Developing Countries: A Reinterpretation of the Sri Lankan Experience. World Bank Economic Review, 1:35-63.

Chaudhuri, Shubham and Martin Ravallion (1994). How Well Do Static Welfare Indicators Identify the Chronically Poor? Journal of Public Economics, 53(3):367-394.

Chen, Shaohua, Gaurav Datt and Martin Ravallion (1993). Is Poverty Increasing in the Developing World? Policy Research Working Papers WPS 1146. World Bank, Washington D.C.

Datt, Gaurav and Martin Ravallion (1993). Regional Disparities, Targeting and Poverty in India.

In Michael Lipton and Jaques van der Gaag (eds). Including the Poor. The World Bank, Washington D.C.

(1992). Growth and Redistribution Components of Changes in Poverty Measures.

Journal of Development Economics, 38:275-295.

Department of Census and Statistics (DCS) (1987). Labour Force and Socio-Economic Survey - 1985/86 Sri Lanka: Preliminary Report. Ministry of Plan Implementation, Colombo. (1989). Bulletin of Selected Retail Prices 1985-1988. Ministry of Policy Planning and Implementation, Colombo. 
- (1991). Statistical Abstract of the Democratic Socialist Republic of Sri Lanka 1991.

Ministry of Policy Planning and Implementation, Colombo.

(1992). Bulletin of Selected Retail Prices 1975-1992. Ministry of Policy Planning and Implementation, Colombo.

Deaton, Angus (1995). The Analysis of Household Surveys: Microeconometric Analysis for Development Policy. Princeton University, mimeo.

Dreze, Jean and Amartya Sen (1989). Hunger and Public Action. Clarendon Press, Oxford.

Edirisinghe, Neville (1990). Poverty in Sri Lanka: Its Extent, Distribution and Characteristics of the Poor. Paper submitted to the World Bank for the Sri Lanka Poverty Alleviation and Employment Project, mimeo.

Foster, James E., Greer J. and Eric Thorbecke (1984). A Class of Decomposable Poverty Measures. Econometrica, 52: 761-766.

Gunaratne, Leslie (1985). Measurement of Poverty in Sri Lanka. World Bank, Washington D.C., mimeo. (1987). The Poorest of the Poor in Sri Lanka. In Alleviation of Poverty in Sri Lanka: A Symposium. Department of Information, Central Bank of Sri Lanka, Colombo.

Glewwe, Paul and Jacques van der Gaag (1990). Identifying the Poor in Developing Countries: Do Different Definitions Matter? World Development, 18:803-814.

Howes, Stephen (1993). Income Distribution: Measurement, Transition and Analysis of Urban China 1981-1990. PhD Dissertation. London School of Economics.

Isenman, Paul (1980). Basic Needs: The Case of Sri Lanka. World Development, 8:237-258.

Kakwani, Nanak (1990). Testing for Significance of Poverty Differences with Application to Cote d'Ivoire. LSMS Working Paper No. 62, World Bank, Washington D.C.

(1993). Performance in Living Standards: An International Comparison. Journal of Development Economics, 41:307-336.

Kanbur, Ravi (1987). Measurement and Alleviation of Poverty. IMF Staff Papers, 34: 60-85.

Lanjouw, Peter and Jenny Lanjouw (1996). Comparing Poverty with Non-Identical Consumption Aggregates: Theory and Illustrations from Equador and Pakistan. World Bank, Washington D.C., 
mimeo.

Lanjouw, Peter and Martin Ravallion (1995). Poverty and Household Size. Economic Journal, 105:1415-1434.

Nanayakkara, A. G. W. and H. A. G. Premaratne (1987). Food Consumption and Nutritional Levels. Section 2.2 in R. B. M. Korale (ed) Income Distribution and Poverty in Sri Lanka, Department of Census and Statistics, Colombo.

Ravallion, Martin (1987). Growth and Equity in Sri Lanka: A Comment. World Bank, Washington D.C., mimeo.

(1994). Poverty Comparisons. Fundamentals of Pure and Applied Economics Series, Harwood Academic Press, New York.

Ravallion, Martin and Benu Bidani (1994). How Robust is a Poverty Profile? The World Bank Economic Review, 8: 75-102.

Rouse, Cecilia Elena (1990). A Study of the Poor in Sri Lanka. Internal Discussion Paper, Asia Regional Series, Report No. IDP 65, The World Bank, Washington D.C.

Sahn, David (1987). Changes in the Living Standards of the Poor in Sri Lanka During a Period of Macroeconomic Adjustment. World Development, 15: 809-830.

Sahn, David and Harold Alderman (1992). The Effect of Food Subsidies on Labor Supply in Sri Lanka. Paper presented at the World Bank Conference on Public Expenditures and the Poor: Incidence and Targeting. June 17-19, Washington D.C.

Sen, Amartya (1981). Public Action and the Quality of Life in Developing Countries. Oxford Bulletin of Economics and Statistics, 43:287-319. (1988). Sri Lanka's Achievements: How and When. In T. N. Srinivasan and P. K. Bardhan (eds) Rural Poverty in South Asia, Oxford University Press, Delhi. 


\section{Annex 1: Expenditure Categories and Estimated Engel Functions}

The Labor Force and Socio-economic Survey of 1985-86 and the Household Income and Expenditure Survey of 1990-91 provide data on over 400 household items of expenditure. Of these, over 200 are food items. About 35 items are for expenditure on consumer durables and non-consumption expenditure. There is a common weekly reference period for all items of food expenditure, while the reference period for non-food expenditures varies by item from a month, a quarter to a year. All expenditures were converted to monthly figures and aggregated into 52 expenditure categories (shown below).

Non-consumption expenditure: Consumer durables and non-consumption expenditure (approximately 35 items) were not included in the construction of the consumption expenditure variable used for the estimation of poverty. Non-consumptionitems were excluded for the obvious reason that they did not represent expenses towards consumption. Consumer durables were excluded on account of measurement errors in the data for these expenditures.

"Food" Expenditure: The 200-odd food expenditure items were aggregated into 38 expenditure categories comprising 36 food items and 2 basic non-food items (kerosene and firewood). Aggregation was based on the availability of information on quantity consumed and on the homogeneity of items in terms of quality and the unit of measurement. Items which had no information on quantity were excluded from this group and included in non-food expenditure (see below). Within each of the 38 "food" expenditure categories, all items have the same unit of measurement, and for any given category, units are the same for both surveys. Unit values were derived from expenditure and quantity data, and these were used to compute regional and national price indices.

"Non-food" expenditure: Besides the non-food consumption items, this class of expenditure categories also includes the food items excluded from the food expenditure categories. Food items that appear here are those which had no quantity information, or were not sufficiently homogenous, or were measured in different units than the rest of the relevant category in the same survey or were measured differently in the two surveys, precluding the possibility of computing meaningful and comparable unit values. The non-food items include all non-food consumption items.

Total household expenditure is defined as the sum of all (consumption) expenditure on food and "non-food" items, or the sum of "food" and "non-food" expenditure. For the purposes of the estimation of the price indices, "food" share is defined as the share of the first group (food expenditure) as a proportion of total household expenditure. 


\section{Food expenditure}

1. Rice

2. Wheat flour, kurakkan, maize

3. Bread

4. Buns and cereal preparations bought outside and consumed inside the household

5. Other cereal preparations

6. Condiments (including chilies and onions)

$7 . \quad$ Dhal

8. Green gram, cowpea \& other pulses

9. Leafy vegetables

10. Other vegetables

11. Breadfruit

12. Yams and potatoes

13. Coconut

14. Beef \& pork

15. Mutton

16. Chicken

17. Other meat

18. Fresh large and shell fish

19. Fresh small fish

20. Dried fish (including jadi and other canned fish)

21. Sprats

22. Milk

23. Milk products

24. Edible oils

25. Fats

26. Eggs

27. Fresh fruit

28. Grapes, dried and canned fruit

29. Tea

30. Coffee

31. Sugar (including jaggery, treacle)

32. Confectioneries

33. Aerated water \& beverages purchased and consumed outside the household (includes soft drinks)

34. Food bought and consumed outside the household

35. Tobacco

36. Betel

37. Kerosene

38. Firewood

\section{Non-food expenditure}

39. Miscellaneous food items: other bakery products (except buns), cereals and jam, other condiments, other pulses and vegetables, lime, jak, other yams and potatoes, coconut milk powder, other meat and fish, curd and yogurt, other milk products, other fruit \& sugar, fruit drinks, ice-cream, other confectioneries, other packeted food, marmite and soymeat, soup cubes, other "other packeted food", pickles, chutney and other miscellaneous food, food outside, (flour preparations, fruits and nuts), liquor \& narcotics (ganja etc.), Pipe and chewing tobacco and other tobacco.

40. Electricity and ordinary gas

41. L.P. gas

42. Housing

43. Light

44. Clothing

45. Non-durables

46. Services

47. Personal care and health

48. Transport and vehicle maintenance

49. Communication

50. Recreation

51. Education

52. Miscellaneous 
Table 1: Spatial and temporal price indices and nominal poverty lines (Rs./person/month at current prices)

\begin{tabular}{|c|c|c|c|c|c|c|c|c|c|}
\hline & \multicolumn{2}{|c|}{ Food poverty line } & \multicolumn{2}{|c|}{$\begin{array}{c}\text { General poverty } \\
\text { line }\end{array}$} & \multicolumn{2}{|c|}{ Food price index } & \multicolumn{2}{|c|}{ General price index } \\
\hline & & $85-86$ & $90-91$ & $85-86$ & $90-91$ & $85-86$ & $90-91$ & $85-86$ & $90-91$ \\
\hline \multirow[t]{2}{*}{ Western } & $\mathbf{R}$ & 200.67 & 395.56 & 241.87 & 471.76 & 100.3 & 197.8 & 99.9 & 194.9 \\
\hline & $\mathrm{U}$ & 217.87 & 423.43 & 256.18 & 501.99 & 108.9 & 211.7 & 105.8 & 207.4 \\
\hline \multirow[t]{2}{*}{ Central } & $\mathbf{R}$ & 196.43 & 381.41 & 235.36 & 463.44 & 98.2 & 190.7 & 97.2 & 191.5 \\
\hline & $\mathrm{U}$ & 207.64 & 398.75 & 248.30 & 490.44 & 103.8 & 199.4 & 102.6 & 202.6 \\
\hline \multirow[t]{2}{*}{ Southern } & $\mathbf{R}$ & 191.04 & 390.94 & 236.43 & 480.34 & 95.5 & 195.5 & 97.7 & 198.4 \\
\hline & $\mathrm{U}$ & 205.75 & 395.84 & 244.73 & 471.84 & 102.9 & 197.9 & 101.1 & 194.9 \\
\hline \multirow{2}{*}{$\begin{array}{l}\text { North } \\
\text { western and } \\
\text { north central }\end{array}$} & $\mathbf{R}$ & 194.65 & 361.37 & 240.48 & 443.40 & 97.3 & 180.7 & 99.3 & 183.2 \\
\hline & $\mathrm{U}$ & 207.25 & 371.59 & 247.97 & 455.72 & 103.6 & 185.8 & 102.4 & 188.3 \\
\hline \multirow[t]{2}{*}{ South central } & $\mathbf{R}$ & 198.45 & 377.50 & 242.31 & 475.20 & 99.2 & 188.7 & 100.1 & 196.3 \\
\hline & $\mathrm{U}$ & 199.60 & 394.62 & 241.20 & 492.98 & 99.8 & 197.3 & 99.6 & 203.7 \\
\hline \multirow{2}{*}{\multicolumn{2}{|c|}{$\begin{array}{l}\text { Rural } \\
\text { Urban }\end{array}$}} & 196.34 & 380.01 & 239.54 & 465.48 & 98.2 & 190.0 & 99.0 & 192.3 \\
\hline & & 213.93 & 413.32 & 252.87 & 494.22 & 107.0 & 206.7 & 104.5 & 204.2 \\
\hline \multicolumn{2}{|l|}{ Sri Lanka } & 200 & 387 & 242.06 & 471.20 & 100 & 193.5 & 100 & 194.7 \\
\hline
\end{tabular}

Note: The estimates in this and all subsequent Tables exclude eight Northern and Eastern districts where the 1990-91 survey was not conducted, and which are also excluded from the 1985-86 survey to maintain comparability. ' $R$ ' and ' $U$ ' refer to the rural and urban sectors. 
Table 2: Population shares, mean consumption and Ginis: 1985-86 and 1990-91

\begin{tabular}{|c|c|c|c|c|c|c|}
\hline & \multicolumn{3}{|c|}{$1985-86$} & \multicolumn{3}{|c|}{$1990-91$} \\
\hline & $\begin{array}{l}\text { Population } \\
\text { share } \\
(\%)\end{array}$ & $\begin{array}{c}\text { Mean } \\
\text { consumption } \\
\text { (Rs./person/ } \\
\text { month) * }\end{array}$ & $\begin{array}{c}\text { Gini } \\
\text { coefficient } \\
(\%)\end{array}$ & $\begin{array}{l}\text { Population } \\
\text { share } \\
(\%)\end{array}$ & $\begin{array}{c}\text { Mean } \\
\text { consumption } \\
\text { (Rs./person/ } \\
\text { month) * }\end{array}$ & $\begin{array}{c}\text { Gini } \\
\text { coefficient } \\
(\%)\end{array}$ \\
\hline Rural & $\begin{array}{c}72.46 \\
(2919)\end{array}$ & 708.29 & 29.87 & $\begin{array}{c}72.50 \\
(2769)\end{array}$ & 743.64 & 27.57 \\
\hline Urban & $\begin{array}{l}20.81 \\
(1604)\end{array}$ & 1038.47 & 35.68 & $\begin{array}{c}20.86 \\
(1573)\end{array}$ & 990.10 & 35.39 \\
\hline Estate & $\begin{array}{r}6.73 \\
(324) \\
\end{array}$ & 763.69 & 24.49 & $\begin{array}{c}6.64 \\
(308) \\
\end{array}$ & 749.93 & 20.17 \\
\hline Sri Lanka & $\begin{array}{c}100 \\
(4847)\end{array}$ & 780.73 & 32.04 & $\begin{array}{c}100 \\
(4650)\end{array}$ & 795.48 & 29.66 \\
\hline
\end{tabular}

Note: * at 1990-91 Sri Lanka prices. The number of sample households is given in parentheses. 
Table 3: Poverty in Sri Lanka by sector: $1985-86$ and 1990-91

\begin{tabular}{|c|c|c|c|c|c|c|}
\hline & \multicolumn{3}{|c|}{$1985-86$} & \multicolumn{3}{|c|}{$1990-91$} \\
\hline & $\begin{array}{l}\text { Headcount } \\
\text { index }\end{array}$ & $\begin{array}{l}\text { Poverty gap } \\
\text { index }\end{array}$ & $\begin{array}{c}\text { Squared } \\
\text { poverty gap } \\
\text { index }\end{array}$ & $\begin{array}{l}\text { Headcount } \\
\text { index }\end{array}$ & $\begin{array}{l}\text { Poverty gap } \\
\text { index }\end{array}$ & $\begin{array}{c}\text { Squared } \\
\text { poverty gap } \\
\text { index }\end{array}$ \\
\hline & \multicolumn{6}{|c|}{ Reference poverty line: Rs. $471.20 /$ person/month * } \\
\hline Rural: & $\begin{array}{l}31.67 \\
(0.86)\end{array}$ & $\begin{array}{c}7.67 \\
(0.27)\end{array}$ & $\begin{array}{c}2.75 \\
(0.13)\end{array}$ & $\begin{array}{l}24.41 \\
(0.82)\end{array}$ & $\begin{array}{c}5.27 \\
(0.23)\end{array}$ & $\begin{array}{c}1.78 \\
(0.11)\end{array}$ \\
\hline Urban & $\begin{array}{c}16.43 \\
(0.93)\end{array}$ & $\begin{array}{c}3.48 \\
(0.25)\end{array}$ & $\begin{array}{c}1.11 \\
(0.11)\end{array}$ & $\begin{array}{c}18.31 \\
(0.98)\end{array}$ & $\begin{array}{c}4.14 \\
(0.28)\end{array}$ & $\begin{array}{c}1.37 \\
(0.12)\end{array}$ \\
\hline Estate & $\begin{array}{r}14.31 \\
(1.95) \\
\end{array}$ & $\begin{array}{c}3.81 \\
(0.62) \\
\end{array}$ & $\begin{array}{r}1.37 \\
(0.27) \\
\end{array}$ & $\begin{array}{r}12.62 \\
(1.89) \\
\end{array}$ & $\begin{array}{c}2.11 \\
(0.43) \\
\end{array}$ & $\begin{array}{c}0.60 \\
(0.17) \\
\end{array}$ \\
\hline \multirow[t]{2}{*}{ Sri Lanka } & $\begin{array}{l}27.33 \\
(0.64) \\
\end{array}$ & $\begin{array}{c}6.54 \\
(0.20) \\
\end{array}$ & $\begin{array}{c}2.31 \\
(0.09) \\
\end{array}$ & $\begin{array}{l}22.36 \\
(0.61) \\
\end{array}$ & $\begin{array}{c}4.82 \\
(0.17) \\
\end{array}$ & $\begin{array}{c}1.62 \\
(0.08) \\
\end{array}$ \\
\hline & \multicolumn{6}{|c|}{ Higher poverty line: Rs. 565.44/person/month * } \\
\hline Rural & $\begin{array}{l}45.48 \\
(0.92)\end{array}$ & $\begin{array}{c}12.81 \\
(0.34)\end{array}$ & $\begin{array}{c}5.04 \\
(0.18)\end{array}$ & $\begin{array}{l}38.05 \\
(0.92)\end{array}$ & $\begin{array}{c}9.55 \\
(0.31)\end{array}$ & $\begin{array}{c}3.49 \\
(0.15)\end{array}$ \\
\hline Urban & $\begin{array}{l}26.78 \\
(1.11)\end{array}$ & $\begin{array}{c}6.52 \\
(0.34)\end{array}$ & $\begin{array}{c}2.29 \\
(0.16)\end{array}$ & $\begin{array}{l}28.43 \\
(1.14)\end{array}$ & $\begin{array}{c}7.34 \\
(0.37)\end{array}$ & $\begin{array}{c}2.70 \\
(0.18)\end{array}$ \\
\hline Estate & $\begin{array}{r}30.85 \\
(2.57) \\
\end{array}$ & $\begin{array}{r}6.79 \\
(0.80) \\
\end{array}$ & $\begin{array}{r}2.54 \\
(0.40) \\
\end{array}$ & $\begin{array}{r}27.51 \\
(2.55) \\
\end{array}$ & $\begin{array}{r}5.17 \\
(0.63) \\
\end{array}$ & $\begin{array}{r}1.50 \\
(0.27) \\
\end{array}$ \\
\hline Sri Lanka & $\begin{array}{r}40.60 \\
(0.71) \\
\end{array}$ & $\begin{array}{r}11.09 \\
(0.25) \\
\end{array}$ & $\begin{array}{r}4.30 \\
(0.13) \\
\end{array}$ & $\begin{array}{c}35.34 \\
(0.70) \\
\end{array}$ & $\begin{array}{c}8.80 \\
(0.23)\end{array}$ & $\begin{array}{c}3.20 \\
(0.11)\end{array}$ \\
\hline
\end{tabular}

Note: * at 1990-91 Sri Lanka prices. All poverty measures are in percentages. The numbers in parentheses are the standard errors of poverty measures. 
Table 4: Sectoral decomposition of change in poverty: 1985-86 to 1990-91

\begin{tabular}{|c|c|c|c|c|c|c|c|}
\hline & \multicolumn{3}{|c|}{ Intersectoral effect } & \multirow{2}{*}{$\begin{array}{l}\text { Inter- } \\
\text { sectoral } \\
\text { population } \\
\text { shift } \\
\end{array}$} & \multirow{2}{*}{$\begin{array}{l}\text { Cov- } \\
\text { ariance } \\
\text { term }\end{array}$} & \multirow{2}{*}{$\begin{array}{l}\text { All } \\
\text { change }\end{array}$} & \multirow{2}{*}{$\begin{array}{c}\text { Change } \\
\text { in } \\
\text { poverty } \\
(\%)\end{array}$} \\
\hline & Rural & Urban & Estate & & & & \\
\hline & \multicolumn{7}{|c|}{ Reference poverty line: Rs. $471.20 /$ person/month * } \\
\hline $\begin{array}{l}\text { Headcount } \\
\text { index }\end{array}$ & 105.71 & -7.84 & 2.29 & -0.17 & 0.01 & 100 & -18.19 \\
\hline $\begin{array}{l}\text { Poverty gap } \\
\text { index }\end{array}$ & 101.49 & -8.00 & 6.66 & -0.09 & -0.06 & 100 & -26.23 \\
\hline \multirow{2}{*}{$\begin{array}{l}\text { Squared poverty } \\
\text { gap index }\end{array}$} & 100.52 & -7.83 & 7.44 & -0.06 & -0.07 & 100 & -30.16 \\
\hline & \multicolumn{7}{|c|}{ Higher poverty line: Rs. 565.44/person/month * } \\
\hline $\begin{array}{l}\text { Headcount } \\
\text { index }\end{array}$ & 102.37 & -6.55 & 4.28 & -0.08 & -0.02 & 100 & -12.96 \\
\hline $\begin{array}{l}\text { Poverty gap } \\
\text { index }\end{array}$ & 102.87 & -7.50 & 4.77 & -0.11 & -0.03 & 100 & -20.67 \\
\hline $\begin{array}{l}\text { Squared poverty } \\
\text { gap index }\end{array}$ & 101.60 & -7.78 & 6.32 & -0.09 & -0.05 & 100 & -25.69 \\
\hline
\end{tabular}

Note: * at 1990-91 Sri Lanka prices. All components are expressed as percentages of the total change in poverty. 
Table 5: Growth and redistribution components of changes in poverty measures: 1985-86 to 1990-91

\begin{tabular}{|c|c|c|c|c|c|}
\hline & & Growth component & $\begin{array}{l}\text { Redistribution } \\
\text { component }\end{array}$ & Residual component & $\begin{array}{l}\text { Total change in } \\
\text { poverty }\end{array}$ \\
\hline \multicolumn{6}{|c|}{ Rural sector: Reference poverty line } \\
\hline Headcount index & $\begin{array}{r}\% \text { pts. } \\
\%\end{array}$ & $\begin{array}{r}-3.70 \\
51 \\
\end{array}$ & $\begin{array}{r}-4.68 \\
65 \\
\end{array}$ & $\begin{array}{r}1.12 \\
-15 \\
\end{array}$ & $\begin{array}{r}-7.25 \\
100 \\
\end{array}$ \\
\hline Poverty gap index & \multirow{2}{*}{$\begin{array}{r}\% \text { pts. } \\
\% \\
\% \text { pts. } \\
\%\end{array}$} & $\begin{array}{r}-1.12 \\
46 \\
\end{array}$ & $\begin{array}{r}-1.42 \\
59 \\
\end{array}$ & $\begin{array}{r}0.14 \\
-6 \\
\end{array}$ & $\begin{array}{r}-2.40 \\
100 \\
\end{array}$ \\
\hline Squared poverty gap index & & $\begin{array}{r}-0.45 \\
46 \\
\end{array}$ & $\begin{array}{r}-0.60 \\
62 \\
\end{array}$ & $\begin{array}{r}0.08 \\
-8 \\
\end{array}$ & $\begin{array}{r}-0.97 \\
100 \\
\end{array}$ \\
\hline \multicolumn{6}{|c|}{ Rural sector: Higher poverty line } \\
\hline Headcount index & $\begin{array}{r}\% \text { pts. } \\
\%\end{array}$ & $\begin{array}{r}-4.27 \\
57 \\
\end{array}$ & $\begin{array}{r}-3.71 \\
50 \\
\end{array}$ & $\begin{array}{r}0.54 \\
-7 \\
\end{array}$ & $\begin{array}{r}-7.43 \\
100 \\
\end{array}$ \\
\hline Poverty gap index & $\begin{array}{r}\% \text { pts. } \\
\%\end{array}$ & $\begin{array}{r}-1.53 \\
47 \\
\end{array}$ & $\begin{array}{r}-1.81 \\
56 \\
\end{array}$ & $\begin{array}{r}0.08 \\
-2 \\
\end{array}$ & $\begin{array}{r}-3.25 \\
100 \\
\end{array}$ \\
\hline Squared poverty gap index & $\begin{array}{r}\% \text { pts. } \\
\% \\
\end{array}$ & $\begin{array}{r}-0.72 \\
46 \\
\end{array}$ & $\begin{array}{r}-0.92 \\
59 \\
\end{array}$ & $\begin{array}{r}0.09 \\
-6 \\
\end{array}$ & $\begin{array}{r}-1.55 \\
100 \\
\end{array}$ \\
\hline \multicolumn{6}{|c|}{ Urban sector: Reference poverty line } \\
\hline Headcount index & $\%$ pts. & $\begin{array}{r}2.24 \\
119 \\
\end{array}$ & $\begin{array}{r}-0.72 \\
-38 \\
\end{array}$ & $\begin{array}{r}0.35 \\
19 \\
\end{array}$ & $\begin{array}{r}1.87 \\
100 \\
\end{array}$ \\
\hline Poverly gap index & $\begin{array}{r}\% \text { pts. } \\
\%\end{array}$ & $\begin{array}{r}0.67 \\
102 \\
\end{array}$ & $\begin{array}{r}0.02 \\
3 \\
\end{array}$ & $\begin{array}{r}-0.04 \\
-6 \\
\end{array}$ & $\begin{array}{r}0.66 \\
100 \\
\end{array}$ \\
\hline Squared poverty gap index & $\begin{array}{r}\% \text { pts. } \\
\%\end{array}$ & $\begin{array}{r}0.25 \\
94 \\
\end{array}$ & $\begin{array}{r}0.02 \\
7 \\
\end{array}$ & $\begin{array}{r}0.00 \\
-1 \\
\end{array}$ & $\begin{array}{r}0.26 \\
100 \\
\end{array}$ \\
\hline \multicolumn{6}{|c|}{ Urban sector: Higher poverty line } \\
\hline Headcount index & $\begin{array}{r}\% \text { pts. } \\
\%\end{array}$ & $\begin{array}{r}2.45 \\
148 \\
\end{array}$ & $\begin{array}{r}-1.00 \\
-60 \\
\end{array}$ & $\begin{array}{r}0.21 \\
13 \\
\end{array}$ & $\begin{array}{r}1.66 \\
100 \\
\end{array}$ \\
\hline Poverty gap index & $\%$ pts. & $\begin{array}{r}1.01 \\
122 \\
\end{array}$ & $\begin{array}{r}-0.14 \\
-17 \\
\end{array}$ & $\begin{array}{r}-0.05 \\
-6 \\
\end{array}$ & $\begin{array}{r}0.83 \\
100 \\
\end{array}$ \\
\hline Squared poverty gap index & $\begin{array}{r}\% \text { pts. } \\
\% \\
\end{array}$ & $\begin{array}{r}0.43 \\
104 \\
\end{array}$ & $\begin{array}{r}0.00 \\
-1 \\
\end{array}$ & $\begin{array}{r}-0.01 \\
-3 \\
\end{array}$ & $\begin{array}{r}0.41 \\
100 \\
\end{array}$ \\
\hline \multicolumn{6}{|c|}{ Estate sector: Reference poverty line } \\
\hline Headcount index & $\begin{array}{r}\% \text { pts. } \\
\%\end{array}$ & $\begin{array}{r}0.20 \\
-12 \\
\end{array}$ & $\begin{array}{r}-2.84 \\
168 \\
\end{array}$ & $\begin{array}{r}0.95 \\
-56 \\
\end{array}$ & $\begin{array}{r}-1.69 \\
100 \\
\end{array}$ \\
\hline Poverty gap index & $\begin{array}{r}\% \text { pts. } \\
\%\end{array}$ & $\begin{array}{r}0.19 \\
-11 \\
\end{array}$ & $\begin{array}{r}-1.88 \\
111 \\
\end{array}$ & $\begin{array}{r}-0.01 \\
0 \\
\end{array}$ & $\begin{array}{r}-1.69 \\
100 \\
\end{array}$ \\
\hline Squared poverty gap index & $\begin{array}{r}\% \text { pts. } \\
\% \\
\end{array}$ & $\begin{array}{r}0.09 \\
-12 \\
\end{array}$ & $\begin{array}{r}-0.82 \\
107 \\
\end{array}$ & $\begin{array}{r}-0.04 \\
5 \\
\end{array}$ & $\begin{array}{r}-0.77 \\
100 \\
\end{array}$ \\
\hline \multicolumn{6}{|c|}{ Estate sector: Higher poverty line } \\
\hline Headcount index & $\%$ pts. & $\begin{array}{r}2.05 \\
-61 \\
\end{array}$ & $\begin{array}{r}-3.96 \\
118 \\
\end{array}$ & $\begin{array}{r}-1.43 \\
43 \\
\end{array}$ & $\begin{array}{r}-3.34 \\
100 \\
\end{array}$ \\
\hline Poverty gap index & $\begin{array}{r}\% \text { pts. } \\
\%\end{array}$ & $\begin{array}{r}0.45 \\
-27 \\
\end{array}$ & $\begin{array}{r}-2.03 \\
125 \\
\end{array}$ & $\begin{array}{r}-0.04 \\
3 \\
\end{array}$ & $\begin{array}{r}-1.62 \\
100 \\
\end{array}$ \\
\hline Squared poverty gap index & $\begin{array}{r}\% \text { pts. } \\
\% \\
\end{array}$ & $\begin{array}{r}0.16 \\
-15 \\
\end{array}$ & $\begin{array}{r}-1.17 \\
112 \\
\end{array}$ & $\begin{array}{r}-0.03 \\
3 \\
\end{array}$ & $\begin{array}{r}-1.04 \\
100 \\
\end{array}$ \\
\hline
\end{tabular}


Table 6: Poverty measures by region and sector for Sri Lanka 1990-91: reference poverty line

\begin{tabular}{|c|c|c|c|c|c|c|}
\hline Region & $\begin{array}{l}\text { Population } \\
\text { share } \\
(\%)\end{array}$ & $\begin{array}{c}\text { Mean } \\
\text { consumption } \\
\text { (Rs/person/ } \\
\text { month) * }\end{array}$ & $\begin{array}{l}\text { Headcount } \\
\text { index }\end{array}$ & $\begin{array}{l}\text { Poverty gap } \\
\text { index }\end{array}$ & $\begin{array}{l}\text { Squared } \\
\text { poverty gap } \\
\text { index }\end{array}$ & $\begin{array}{l}\text { Gini } \\
\text { coeff. }\end{array}$ \\
\hline Western & 30.29 & 943.84 & $\begin{array}{l}19.30 \\
(1.12) \\
\end{array}$ & $\begin{array}{r}3.96 \\
(0.30) \\
\end{array}$ & $\begin{array}{r}1.28 \\
(0.14) \\
\end{array}$ & 34.8 \\
\hline Urban & 14.20 & 1050.81 & $\begin{array}{l}17.45 \\
(1.35)\end{array}$ & $\begin{array}{c}4.10 \\
(0.39)\end{array}$ & $\begin{array}{c}1.37 \\
(0.17)\end{array}$ & 37.5 \\
\hline Rural & 16.09 & 849.40 & $\begin{array}{l}20.93 \\
(1.95) \\
\end{array}$ & $\begin{array}{c}3.85 \\
(0.49) \\
\end{array}$ & $\begin{array}{c}1.20 \\
(0.22) \\
\end{array}$ & 31.1 \\
\hline Central & 15.90 & 713.52 & $\begin{array}{r}23.73 \\
(1.50) \\
\end{array}$ & $\begin{array}{c}5.53 \\
(0.45) \\
\end{array}$ & $\begin{array}{c}1.94 \\
(0.20) \\
\end{array}$ & 25.4 \\
\hline Urban & 1.59 & 886.52 & $\begin{array}{l}21.00 \\
(2.96)\end{array}$ & $\begin{array}{c}4.23 \\
(0.78)\end{array}$ & $\begin{array}{c}1.33 \\
(0.32)\end{array}$ & 29.6 \\
\hline Rural & 14.32 & 694.34 & $\begin{array}{l}24.03 \\
(1.72) \\
\end{array}$ & $\begin{array}{r}5.67 \\
(0.52) \\
\end{array}$ & $\begin{array}{r}2.00 \\
(0.24) \\
\end{array}$ & 24.4 \\
\hline Southern & 14.48 & 733.03 & $\begin{array}{l}24.23 \\
(1.54) \\
\end{array}$ & $\begin{array}{r}4.93 \\
(0.42) \\
\end{array}$ & $\begin{array}{c}1.61 \\
(0.18) \\
\end{array}$ & 26.6 \\
\hline Urban & 2.47 & 846.28 & $\begin{array}{l}19.86 \\
(2.48)\end{array}$ & $\begin{array}{c}4.25 \\
(0.69)\end{array}$ & $\begin{array}{c}1.42 \\
(0.30)\end{array}$ & 30.0 \\
\hline Rural & 12.01 & 709.80 & $\begin{array}{l}25.12 \\
(1.90) \\
\end{array}$ & $\begin{array}{r}5.07 \\
(0.52) \\
\end{array}$ & $\begin{array}{r}1.64 \\
(0.22) \\
\end{array}$ & 25.4 \\
\hline $\begin{array}{l}N . \text { Western \& } \\
N \text {. Central } \\
\end{array}$ & 20.19 & 743.66 & $\begin{array}{l}22.34 \\
(1.37) \\
\end{array}$ & $\begin{array}{c}4.91 \\
(0.39) \\
\end{array}$ & $\begin{array}{c}1.62 \\
(0.17) \\
\end{array}$ & 26.4 \\
\hline Urban & 1.20 & 875.38 & $\begin{array}{l}18.10 \\
(2.98)\end{array}$ & $\begin{array}{c}3.87 \\
(0.89)\end{array}$ & $\begin{array}{c}1.48 \\
(0.48)\end{array}$ & 27.5 \\
\hline Rural & 18.99 & 735.32 & $\begin{array}{l}22.61 \\
(1.52) \\
\end{array}$ & $\begin{array}{r}4.98 \\
(0.43) \\
\end{array}$ & $\begin{array}{r}1.63 \\
(0.19) \\
\end{array}$ & 26.2 \\
\hline South Central & 19.14 & 730.68 & $\begin{array}{r}24.65 \\
(1.43) \\
\end{array}$ & $\begin{array}{r}5.41 \\
(0.42) \\
\end{array}$ & $\begin{array}{r}1.88 \\
(0.20) \\
\end{array}$ & 26.0 \\
\hline Urban & 1.41 & 844.06 & $\begin{array}{l}21.36 \\
(3.23)\end{array}$ & $\begin{array}{c}4.49 \\
(0.83)\end{array}$ & $\begin{array}{c}1.31 \\
(0.31)\end{array}$ & 27.8 \\
\hline Rural & 17.73 & 721.68 & $\begin{array}{l}24.92 \\
(1.58) \\
\end{array}$ & $\begin{array}{r}5.49 \\
(0.47) \\
\end{array}$ & $\begin{array}{r}1.92 \\
(0.22) \\
\end{array}$ & 25.7 \\
\hline Total & 100 & 795.48 & $\begin{array}{r}22.36 \\
(0.61) \\
\end{array}$ & $\begin{array}{c}4.82 \\
(0.17) \\
\end{array}$ & $\begin{array}{r}1.62 \\
(0.08) \\
\end{array}$ & 29.7 \\
\hline
\end{tabular}

Note: * at 1990-91 Sri Lanka prices. All poverty measures and the Gini coefficients are expressed as percentages. The numbers in parentheses are the standard errors of poverty measures. 
Table 7: Poverty measures by industry of employment: reference poverty line (Rs. 471.20 /person/month *)

\begin{tabular}{|c|c|c|c|c|c|c|}
\hline Industry group & $\begin{array}{c}\text { Population } \\
\text { share } \\
(\%)\end{array}$ & $\begin{array}{c}\text { Mean } \\
\text { consump- } \\
\text { tion * }\end{array}$ & $\begin{array}{l}\text { Headcount } \\
\text { index }\end{array}$ & $\begin{array}{l}\text { Poverty } \\
\text { gap index }\end{array}$ & $\begin{array}{c}\text { Squared } \\
\text { poverty } \\
\text { gap index }\end{array}$ & $\begin{array}{l}\text { Gini } \\
\text { coeff. }\end{array}$ \\
\hline \multicolumn{7}{|c|}{$1990-91$} \\
\hline $\begin{array}{l}\text { Agriculture, forestry, } \\
\text { fishing }\end{array}$ & 40.5 & 700.03 & $\begin{array}{r}23.59 \\
(0.76) \\
\end{array}$ & $\begin{array}{c}4.92 \\
(0.21) \\
\end{array}$ & $\begin{array}{r}1.57 \\
(0.09) \\
\end{array}$ & 24.2 \\
\hline Mining, quarrying & 1.7 & 682.91 & $\begin{array}{l}33.10 \\
(4.39) \\
\end{array}$ & $\begin{array}{c}8.76 \\
(1.58) \\
\end{array}$ & $\begin{array}{c}3.63 \\
(0.81) \\
\end{array}$ & 29.5 \\
\hline $\begin{array}{l}\text { Manufacturing, } \\
\text { electricity, gas, water }\end{array}$ & 13.2 & 811.71 & $\begin{array}{l}22.01 \\
(1.34) \\
\end{array}$ & $\begin{array}{c}4.78 \\
(0.38) \\
\end{array}$ & $\begin{array}{r}1.63 \\
(0.19) \\
\end{array}$ & 30.5 \\
\hline Construction & 4.5 & 716.50 & $\begin{array}{l}29.83 \\
(2.61) \\
\end{array}$ & $\begin{array}{r}6.04 \\
(0.74) \\
\end{array}$ & $\begin{array}{c}2.06 \\
(0.36)\end{array}$ & 29.6 \\
\hline $\begin{array}{l}\text { Trade, hotels, finance, } \\
\text { insurance, real estate }\end{array}$ & 13.0 & 913.13 & $\begin{array}{r}18.44 \\
(1.19) \\
\end{array}$ & $\begin{array}{r}4.30 \\
(0.36) \\
\end{array}$ & $\begin{array}{r}1.58 \\
(0.17) \\
\end{array}$ & 32.9 \\
\hline $\begin{array}{l}\text { Transport, storage, } \\
\text { communications }\end{array}$ & 6.2 & 897.72 & $\begin{array}{l}10.44 \\
(1.56)\end{array}$ & $\begin{array}{c}1.81 \\
(0.39)\end{array}$ & $\begin{array}{c}0.63 \\
(0.18)\end{array}$ & 26.9 \\
\hline $\begin{array}{l}\text { Commercial \& social } \\
\text { services }\end{array}$ & 15.4 & 989.41 & $\begin{array}{l}16.17 \\
(1.02) \\
\end{array}$ & $\begin{array}{c}3.09 \\
(0.25) \\
\end{array}$ & $\begin{array}{c}0.91 \\
(0.10) \\
\end{array}$ & 32.5 \\
\hline Unclassified & 5.4 & 532.12 & $\begin{array}{l}46.75 \\
(2.63) \\
\end{array}$ & $\begin{array}{l}11.85 \\
(0.89) \\
\end{array}$ & $\begin{array}{r}4.25 \\
(0.44) \\
\end{array}$ & 23.5 \\
\hline \multicolumn{7}{|c|}{$1985-86$} \\
\hline $\begin{array}{l}\text { Agriculture, forestry, } \\
\text { fishing }\end{array}$ & 45.1 & 664.27 & $\begin{array}{l}33.11 \\
(0.75)\end{array}$ & $\begin{array}{c}8.00 \\
(0.24) \\
\end{array}$ & $\begin{array}{c}2.84 \\
(0.11)\end{array}$ & 27.8 \\
\hline Mining, quarrying & 1.2 & 588.75 & $\begin{array}{l}46.31 \\
(5.32) \\
\end{array}$ & $\begin{array}{l}13.03 \\
(2.06) \\
\end{array}$ & $\begin{array}{c}5.41 \\
(1.06) \\
\end{array}$ & 31.1 \\
\hline $\begin{array}{l}\text { Manuffacturing, } \\
\text { electricity, gas, water }\end{array}$ & 11.7 & 759.49 & $\begin{array}{l}28.57 \\
(1.41)\end{array}$ & $\begin{array}{c}6.77 \\
(0.42) \\
\end{array}$ & $\begin{array}{c}2.30 \\
(0.19)\end{array}$ & 30.5 \\
\hline Construction & 5.2 & 671.41 & $\begin{array}{l}31.05 \\
(2.41) \\
\end{array}$ & $\begin{array}{c}6.65 \\
(0.69) \\
\end{array}$ & $\begin{array}{c}2.20 \\
(0.30) \\
\end{array}$ & 27.1 \\
\hline $\begin{array}{l}\text { Trade, hotels, finance, } \\
\text { insurance, real estate }\end{array}$ & 13.0 & 920.98 & $\begin{array}{r}17.92 \\
(1.16) \\
\end{array}$ & $\begin{array}{c}3.69 \\
(0.30) \\
\end{array}$ & $\begin{array}{r}1.10 \\
(0.12) \\
\end{array}$ & 31.7 \\
\hline $\begin{array}{l}\text { Transport, storage, } \\
\text { communications }\end{array}$ & 5.6 & 903.58 & $\begin{array}{r}13.30 \\
(1.78) \\
\end{array}$ & $\begin{array}{c}2.43 \\
(0.41) \\
\end{array}$ & $\begin{array}{r}0.66 \\
(0.16) \\
\end{array}$ & 30.1 \\
\hline $\begin{array}{l}\text { Commercial \& social } \\
\text { services }\end{array}$ & 14.3 & 1120.22 & $\begin{array}{l}12.10 \\
(0.89)\end{array}$ & $\begin{array}{c}2.58 \\
(0.24)\end{array}$ & $\begin{array}{c}0.86 \\
(0.12)\end{array}$ & 34.1 \\
\hline Unclassified & 3.8 & 492.90 & $\begin{array}{l}55.75 \\
(3.18) \\
\end{array}$ & $\begin{array}{r}16.73 \\
(1.25) \\
\end{array}$ & $\begin{array}{c}6.61 \\
(0.68) \\
\end{array}$ & 26.9 \\
\hline
\end{tabular}

Note: * Rs. per person per month at 1990-91 Sri Lanka prices. All poverty measures and the Gini coefficients are expressed as percentages. The numbers in parentheses are the standard errors of poverty measures. 
Table 8: Changes in poverty by employment sectors and their contribution to change in national poverty: reference poverty line

\begin{tabular}{|c|c|c|c|c|c|c|c|c|}
\hline \multirow[t]{2}{*}{ Industry group } & \multicolumn{5}{|c|}{ Percentage change between $1985-86$ and $1990-91$} & \multicolumn{3}{|c|}{$\begin{array}{l}\text { Percentage contribution to } \\
\text { change in national poverty }\end{array}$} \\
\hline & Mean & Gini & $\mathrm{H}$ & PG & SPG & $\mathrm{H}$ & PG & SPG \\
\hline $\begin{array}{l}\text { Agriculture, } \\
\text { forestry, fishing }\end{array}$ & 5.4 & -13.1 & -28.8 & -38.5 & -44.8 & 86.4 & 80.8 & 83.0 \\
\hline Mining, quarrying & 16.0 & -5.2 & -28.5 & -32.8 & -33.0 & 3.3 & 3.1 & 3.2 \\
\hline $\begin{array}{l}\text { Manufacturing, } \\
\text { elec., gas, water }\end{array}$ & 6.9 & 0.0 & -23.0 & -29.3 & -28.9 & 15.5 & 13.5 & 11.3 \\
\hline Construction & 6.7 & 9.1 & -3.9 & -9.1 & -6.3 & 1.3 & 1.8 & 1.0 \\
\hline $\begin{array}{l}\text { Trade, hotels, } \\
\text { finance, insurance, } \\
\text { real estate }\end{array}$ & -0.9 & 4.0 & 2.9 & 16.5 & 43.4 & -1.4 & -4.6 & -9.0 \\
\hline $\begin{array}{l}\text { Transport, storage, } \\
\text { communications }\end{array}$ & -0.6 & -10.6 & -21.5 & -25.2 & -5.6 & 3.3 & 2.0 & 0.3 \\
\hline $\begin{array}{l}\text { Commercial \& } \\
\text { social services }\end{array}$ & -11.7 & -4.9 & 33.7 & 19.7 & 6.1 & -11.7 & -4.2 & -1.1 \\
\hline Unclassified & 8.0 & -12.5 & -16.1 & -29.2 & -35.8 & 6.9 & 10.7 & 13.0 \\
\hline $\begin{array}{l}\text { Inter-sectoral } \\
\text { population shift }+ \\
\text { interaction effect }\end{array}$ & & & & & & -3.4 & -3.2 & -1.8 \\
\hline Sri Lanka & 1.9 & -7.4 & -18.2 & -26.2 & -30.2 & 100 & 100 & 100 \\
\hline
\end{tabular}

Note: Mean $=$ mean per capita consumption per month at 1990-91 Sri Lanka prices; $H=$ headcount index; PG $=$ poverty gap index; SPG = squared poverty gap index. 
Table 9: Poverty measures for male and female headed households by sector for Sri Lanka 1990-91 and 1985-86: reference poverty line

\begin{tabular}{|c|c|c|c|c|c|c|}
\hline & $\begin{array}{l}\text { Population } \\
\text { share } \\
(\%)\end{array}$ & $\begin{array}{c}\text { Mean } \\
\text { consumption } \\
\text { (Rs/person/ } \\
\text { month) }{ }^{*}\end{array}$ & $\begin{array}{l}\text { Headcount } \\
\text { index }\end{array}$ & $\begin{array}{l}\text { Poverty gap } \\
\text { index }\end{array}$ & $\begin{array}{l}\text { Squared } \\
\text { poverty gap } \\
\text { index }\end{array}$ & $\begin{array}{l}\text { Gini } \\
\text { coeff. }\end{array}$ \\
\hline \multicolumn{7}{|l|}{ 1990-91 Urban } \\
\hline Male-headed & 16.7 & 1022.42 & $\begin{array}{l}17.17 \\
(1.07)\end{array}$ & $\begin{array}{c}3.81 \\
(0.30)\end{array}$ & $\begin{array}{c}1.25 \\
(0.14)\end{array}$ & 35.2 \\
\hline Female-headed & 4.1 & 871.93 & $\begin{array}{l}22.65 \\
(2.35) \\
\end{array}$ & $\begin{array}{c}5.45 \\
(0.70) \\
\end{array}$ & $\begin{array}{c}1.84 \\
(0.30) \\
\end{array}$ & 35.4 \\
\hline \multicolumn{7}{|l|}{ 1990-91 Rural } \\
\hline Male-headed & 66.7 & 743.97 & $\begin{array}{l}23.23 \\
(0.85)\end{array}$ & $\begin{array}{c}4.93 \\
(0.24)\end{array}$ & $\begin{array}{c}1.68 \\
(0.11)\end{array}$ & 27.2 \\
\hline Female-headed & 12.6 & 742.26 & $\begin{array}{l}24.27 \\
(1.77)\end{array}$ & $\begin{array}{c}5.33 \\
(0.48)\end{array}$ & $\begin{array}{c}1.66 \\
(0.20)\end{array}$ & 25.9 \\
\hline \multicolumn{7}{|l|}{ 1990-91 Total } \\
\hline Male-headed & 83.4 & 800.57 & $\begin{array}{c}22.02 \\
(0.68)\end{array}$ & $\begin{array}{c}4.70 \\
(0.19)\end{array}$ & $\begin{array}{c}1.59 \\
(0.09)\end{array}$ & 29.9 \\
\hline Female-headed & 16.6 & 771.97 & $\begin{array}{l}23.87 \\
(1.42)\end{array}$ & $\begin{array}{c}5.36 \\
(0.40)\end{array}$ & $\begin{array}{c}1.71 \\
(0.17)\end{array}$ & 28.6 \\
\hline \multicolumn{7}{|l|}{ 1985-86 Urban } \\
\hline Male-headed & 16.2 & 1069.86 & $\begin{array}{l}15.53 \\
(1.03)\end{array}$ & $\begin{array}{c}3.25 \\
(0.27)\end{array}$ & $\begin{array}{c}0.98 \\
(0.11)\end{array}$ & 35.6 \\
\hline Female-headed & 4.6 & 929.19 & $\begin{array}{l}19.62 \\
(2.10)\end{array}$ & $\begin{array}{c}4.28 \\
(0.62)\end{array}$ & $\begin{array}{c}1.55 \\
(0.34)\end{array}$ & 35.2 \\
\hline \multicolumn{7}{|l|}{ 1985-86 Rural } \\
\hline Male-headed & 66.4 & 714.56 & $\begin{array}{l}29.92 \\
(0.89)\end{array}$ & $\begin{array}{c}7.12 \\
(0.27)\end{array}$ & $\begin{array}{c}2.50 \\
(0.13)\end{array}$ & 29.4 \\
\hline Female-headed & 12.8 & 704.32 & $\begin{array}{l}31.68 \\
(1.92)\end{array}$ & $\begin{array}{c}3.50 \\
0.66)\end{array}$ & $\begin{array}{c}3.30 \\
(0.35)\end{array}$ & 29.8 \\
\hline \multicolumn{7}{|l|}{ 1985-86 Total } \\
\hline Male-headed & 82.6 & 784.18 & $\begin{array}{l}27.10 \\
(0.71)\end{array}$ & $\begin{array}{c}6.36 \\
(0.21)\end{array}$ & $\begin{array}{c}2.20 \\
(0.10)\end{array}$ & 32.1 \\
\hline Female-headed & 17.4 & 764.05 & $\begin{array}{l}28.47 \\
(1.47)\end{array}$ & $\begin{array}{c}7.38 \\
(0.49)\end{array}$ & $\begin{array}{c}2.84 \\
(0.26)\end{array}$ & 32.0 \\
\hline
\end{tabular}

Note: * at 1990-91 Sri Lanka prices. All poverty measures and the Gini coefficients are expressed as percentages. The numbers in parentheses are the standard errors of poverty measures. 
Table 10: Household size and composition by percentage of the reference poverty line 1990-91

\begin{tabular}{|c|c|c|c|c|c|}
\hline \multirow{2}{*}{$\begin{array}{l}\text { Percentage of } \\
\text { poverty line }\end{array}$} & \multicolumn{4}{|c|}{ Percentage of the population within the age groups } & \multirow{2}{*}{$\begin{array}{l}\text { Household } \\
\text { size }\end{array}$} \\
\hline & under 10 & $10-15$ & $15-60$ & over 60 & \\
\hline $0-50$ & 28.6 & 14.3 & 51.2 & 5.9 & 7.12 \\
\hline $50-80$ & 24.5 & 14.6 & 54.9 & 6 & 5.90 \\
\hline $80-100$ & 23.7 & 14.3 & 55.2 & 6.9 & 5.79 \\
\hline $100-120$ & 22.9 & 14.6 & 55.8 & 6.8 & 5.39 \\
\hline $120-150$ & 20.2 & 12.7 & 59.2 & 8.1 & 5.11 \\
\hline $150-200$ & 17.1 & 11.9 & 62.1 & 8.9 & 4.76 \\
\hline $200-250$ & 14.5 & 9.9 & 63.6 & 11.9 & 4.31 \\
\hline $250-300$ & 13.2 & 9.7 & 64.6 & 12.6 & 4.04 \\
\hline $300-400$ & 11.6 & 7.1 & 69 & 12.4 & 3.65 \\
\hline$>400$ & 9.7 & 10 & 66.6 & 13.7 & 3.60 \\
\hline $\begin{array}{l}0-100 \\
\text { (ultra poor) } \\
\end{array}$ & 24.5 & 14.4 & 54.6 & 6.5 & 5.92 \\
\hline $\begin{array}{l}0-120 \\
\text { (poor) }\end{array}$ & 23.8 & 14.5 & 55.1 & 6.6 & 5.39 \\
\hline $\begin{array}{l}>120 \\
\text { (non-poor) }\end{array}$ & 16.5 & 11.1 & 62.4 & 9.9 & 4.54 \\
\hline All & 19.1 & 12.3 & 59.8 & 8.7 & 4.89 \\
\hline
\end{tabular}


Table 11: Literacy and schooling by percentage of the reference poverty line 1990-91

\begin{tabular}{|c|c|c|c|c|}
\hline \multirow{2}{*}{$\begin{array}{l}\text { Percentage of } \\
\text { poverty line }\end{array}$} & \multicolumn{2}{|c|}{ Literacy rate } & \multicolumn{2}{|c|}{ Average years of schooling } \\
\hline & Male & Female & Male & Female \\
\hline $0-50$ & 80.9 & 80.2 & 5.4 & 5 \\
\hline $50-80$ & 82.2 & 78.3 & 5.7 & 5.6 \\
\hline $80-100$ & 86 & 80.1 & 6.1 & 5.8 \\
\hline $100-120$ & 88.5 & 83.8 & 6.6 & 6.5 \\
\hline $120-150$ & 90.6 & 82.1 & 7 & 6.7 \\
\hline $150-200$ & 90.4 & 83.7 & 7 & 6.9 \\
\hline $200-250$ & 94.6 & 86.8 & 8.1 & 7.7 \\
\hline $250-300$ & 95.7 & 87.3 & 8.5 & 7.9 \\
\hline $300-400$ & 94.1 & 91.3 & 9.1 & 8.9 \\
\hline$>400$ & 96.7 & 93.9 & 10 & 9.7 \\
\hline $0-100$ (ultra poor) & 84.2 & 79.5 & 5.9 & 5.7 \\
\hline $0-120$ (poor) & 85.8 & 81.1 & 6.2 & 6 \\
\hline$>120$ (non-poor) & 92.3 & 85.2 & 7.7 & 7.4 \\
\hline All & 90.1 & 83.8 & 7.2 & 6.9 \\
\hline
\end{tabular}

Note: Literacy rate is defined as the percentage of literates in the population aged 10 or more years. Average years of schooling also refer to persons aged 10 or more years. 
Table 12: Literacy and schooling for the poor and the non-poor in urban and rural sectors 1990-91

\begin{tabular}{|c|c|c|c|c|}
\hline \multirow{2}{*}{$\begin{array}{l}\text { Percentage of } \\
\text { poverty line }\end{array}$} & \multicolumn{2}{|c|}{ Literacy rate } & \multicolumn{2}{|c|}{ Average years of schooling } \\
\hline & Male & Female & Male & Female \\
\hline \multicolumn{5}{|c|}{ Urban } \\
\hline $0-100$ (ultra poor) & 87.4 & 83.7 & 6.5 & 6.1 \\
\hline $0-120$ (poor) & 88.5 & 85.4 & 6.8 & 6.4 \\
\hline$>120$ (non-poor) & 96.3 & 92.5 & 8.8 & 8.5 \\
\hline All & 94.1 & 90.6 & 8.2 & 7.9 \\
\hline \multicolumn{5}{|c|}{ Rural (including estate) } \\
\hline $0-100$ (ultra poor) & 83.5 & 78.6 & 5.8 & 5.6 \\
\hline $0-120$ (poor) & 85.2 & 80.2 & 6 & 5.9 \\
\hline$>120$ (non-poor) & 91.1 & 82.9 & 7.3 & 7.1 \\
\hline All & 89 & 82 & 6.9 & 6.6 \\
\hline
\end{tabular}

Note: Literacy rate is defined as the percentage of literates in the population aged 10 or more years. Average years of schooling also refer to persons aged 10 or more years. 
Table 13: Labor force participation, employment and unemployment by percentage of the reference poverty line 1990-91

\begin{tabular}{||l|c|c|c|c||}
\hline \multirow{2}{*}{$\begin{array}{l}\text { Percentage of } \\
\text { poverty line }\end{array}$} & \multicolumn{3}{|c|}{ Share in population above 10 years (\%) } & \multirow{2}{*}{$\begin{array}{c}\text { Unemployment } \\
\text { rate (\%) } \\
{[2 /(1+2)]}\end{array}$} \\
\cline { 2 - 5 } & $\begin{array}{c}\text { Employed } \\
{[1]}\end{array}$ & $\begin{array}{c}\text { Unemployed } \\
{[2]}\end{array}$ & $\begin{array}{c}\text { Not in labor force } \\
{[3]}\end{array}$ & \multicolumn{2}{|c|}{} \\
\hline $0-80$ & 34.7 & 11.8 & 53.5 & 25.4 \\
\hline $80-100$ & 36.8 & 8.5 & 54.7 & 18.8 \\
\hline $100-120$ & 39.0 & 8.5 & 52.5 & 17.9 \\
\hline $120-150$ & 41.1 & 8.1 & 50.8 & 16.5 \\
\hline $150-200$ & 42.4 & 8.1 & 49.5 & 16.0 \\
\hline $200-250$ & 41.8 & 6.9 & 51.3 & 14.2 \\
\hline $250-300$ & 47.3 & 5.7 & 47.0 & 10.8 \\
\hline $300-400$ & 45.4 & 5.6 & 49.0 & 11.0 \\
\hline$>400$ & 48.0 & 2.8 & 49.2 & 5.5 \\
\hline
\end{tabular}

Table 14: Age-specific labor force participation rates among the poor and the non-poor 1990-91

\begin{tabular}{|c|c|c|c|}
\hline \multirow{2}{*}{$\begin{array}{l}\text { Percentage of poverty } \\
\text { line }\end{array}$} & \multicolumn{3}{|c|}{ Age-specific labor force participation rates } \\
\hline & $10-15$ & $15-60$ & $>60$ \\
\hline $0-100$ (ultra poor) & 4.7 & 58.5 & 29.9 \\
\hline $0-120$ (poor) & 4.6 & 59.2 & 31.9 \\
\hline$>120$ (non-poor) & 3.6 & 61.0 & 34.1 \\
\hline All & 3.9 & 60.4 & 33.5 \\
\hline
\end{tabular}


Table 15: Occupational distribution of those employed by percentage of the reference poverty line 1990-91

\begin{tabular}{|c|c|c|c|c|c|c|c|}
\hline \multirow{3}{*}{$\begin{array}{l}\text { Percentage } \\
\text { of poverty } \\
\text { line }\end{array}$} & \multicolumn{7}{|c|}{ Share among those employed (\%) } \\
\hline & \multicolumn{2}{|c|}{ Agriculture } & \multicolumn{2}{|c|}{ Urban non-agriculture } & \multicolumn{2}{|c|}{ Rural non-agriculture } & \multirow{2}{*}{$\begin{array}{c}\text { Unclassifi } \\
\text { ed }\end{array}$} \\
\hline & Employees & $\begin{array}{c}\text { Self- } \\
\text { employed }\end{array}$ & Employees & $\begin{array}{c}\text { Self- } \\
\text { employed }\end{array}$ & Employees & $\begin{array}{c}\text { Self- } \\
\text { employed }\end{array}$ & \\
\hline $0-80$ & 24.5 & 21.0 & 9.5 & 2.6 & 20.5 & 6.9 & 15.3 \\
\hline $80-100$ & 23.1 & 20.4 & 8.7 & 3.3 & 24.2 & 10.3 & 10.1 \\
\hline $100-120$ & 23.6 & 25.6 & 9.0 & 4.1 & 20.0 & 10.3 & 7.7 \\
\hline $120-150$ & 23.4 & 27.5 & 10.0 & 3.2 & 24.1 & 7.3 & 4.6 \\
\hline $150-200$ & 22.9 & 26.4 & 8.7 & 3.3 & 24.8 & 11.1 & 3.1 \\
\hline $200-250$ & 15.1 & 20.6 & 14.8 & 5.0 & 27.5 & 14.8 & 1.9 \\
\hline $250-300$ & 12.9 & 20.1 & 21.4 & 5.3 & 29.8 & 9.1 & 1.5 \\
\hline $300-400$ & 8.4 & 20.0 & 22.9 & 6.2 & 31.1 & 10.1 & 0.9 \\
\hline$>400$ & 2.3 & 12.7 & 31.3 & 13.8 & 26.9 & 12.9 & 0.4 \\
\hline $\begin{array}{l}0-100 \\
\text { (ultra-poor) }\end{array}$ & 23.7 & 20.7 & 8.9 & 3.1 & 22.6 & 8.9 & 12.3 \\
\hline $\begin{array}{l}0-120 \\
\text { (poor) }\end{array}$ & 23.8 & 22.7 & 8.9 & 3.5 & 21.6 & 9.5 & 10.5 \\
\hline $\begin{array}{l}>120 \\
\text { (non-poor) }\end{array}$ & 18.4 & 23.8 & 13.8 & 4.7 & 26.1 & 10.5 & 2.8 \\
\hline All & 20.0 & 23.4 & 12.4 & 4.1 & 24.6 & 10.2 & 5.1 \\
\hline
\end{tabular}


Table 16: Poverty measures for self-employed agricultural households by land ownership (poverty line $=$ Rs. 471.20 /person/month)

\begin{tabular}{|c|c|c|c|c|c|c|}
\hline $\begin{array}{l}\text { Land owned } \\
\text { by the } \\
\text { houselhold } \\
\text { (in acres) }\end{array}$ & $\begin{array}{l}\text { Population } \\
\text { share }\end{array}$ & $\begin{array}{c}\text { Mean } \\
\text { consump- } \\
\text { tion * }\end{array}$ & $\begin{array}{l}\text { Headcount } \\
\text { index }\end{array}$ & $\begin{array}{l}\text { Poverty gap } \\
\text { index }\end{array}$ & $\begin{array}{l}\text { Squared } \\
\text { poverty gap } \\
\text { index }\end{array}$ & $\begin{array}{c}\text { Gini } \\
\text { coefficient }\end{array}$ \\
\hline \multicolumn{7}{|l|}{$1990-91$} \\
\hline less than 1 & 30.2 & 680.44 & $\begin{array}{l}24.46 \\
(1.83)\end{array}$ & $\begin{array}{c}5.22 \\
(0.50)\end{array}$ & $\begin{array}{c}1.66 \\
(0.21)\end{array}$ & 23.0 \\
\hline $1-3$ & 37.5 & 722.96 & $\begin{array}{l}18.06 \\
(1.52)\end{array}$ & $\begin{array}{c}3.40 \\
(0.36)\end{array}$ & $\begin{array}{c}0.93 \\
(0.13)\end{array}$ & 23.6 \\
\hline 3 and above & 32.3 & 817.60 & $\begin{array}{l}13.65 \\
(1.53)\end{array}$ & $\begin{array}{c}2.68 \\
(0.38)\end{array}$ & $\begin{array}{c}0.80 \\
(0.16)\end{array}$ & 23.9 \\
\hline \multicolumn{7}{|l|}{$1985-86$} \\
\hline less than 1 & 25.6 & 631.04 & $\begin{array}{l}38.30 \\
(2.06)\end{array}$ & $\begin{array}{c}8.46 \\
(0.64)\end{array}$ & $\begin{array}{c}3.00 \\
(0.32)\end{array}$ & 26.7 \\
\hline $1-3$ & 33.6 & 649.34 & $\begin{array}{l}36.27 \\
(1.77)\end{array}$ & $\begin{array}{l}8.94 \\
(0.59)\end{array}$ & $\begin{array}{c}3.34 \\
(0.31)\end{array}$ & 29.5 \\
\hline 3 and above & 40.8 & 764.53 & $\begin{array}{r}19.43 \\
(1.33) \\
\end{array}$ & $\begin{array}{r}3.33 \\
(0.31) \\
\end{array}$ & $\begin{array}{r}0.96 \\
(0.12) \\
\end{array}$ & 26.3 \\
\hline
\end{tabular}

Note: * Rs. per person per month at 1990-91 Sri Lanka prices. All poverty measures and the Gini coefficients are expressed as percentages. The numbers in parentheses are the standard errors of poverty measures. 
Table 17: Share of food items in total expenditure by percentage of the reference poverty line 1990-91

\begin{tabular}{|c|c|c|c|c|c|c|c|c|c|}
\hline $\begin{array}{l}\text { Percentage } \\
\text { of poverty } \\
\text { line }\end{array}$ & Rice & $\begin{array}{l}\text { Other } \\
\text { cereals }\end{array}$ & Pulses & Coconut & $\begin{array}{l}\text { Fruits and } \\
\text { vegetables }\end{array}$ & $\begin{array}{l}\text { Meat and } \\
\text { Fish }\end{array}$ & $\begin{array}{c}\text { Milk, dairy } \\
\text { products }\end{array}$ & $\begin{array}{l}\text { Other } \\
\text { food }\end{array}$ & $\begin{array}{c}\text { All } \\
\text { Food }\end{array}$ \\
\hline $0-50$ & 28.8 & 7.1 & 3.8 & 5.5 & 7.6 & 4.7 & 1.5 & 21.7 & 80.7 \\
\hline $50-80$ & 27.1 & 5.6 & 3.1 & 4.7 & 7.1 & 4.2 & 2.8 & 25.4 & 80 \\
\hline $80-100$ & 24.4 & 5.7 & 2.9 & 4 & 7.1 & 4.9 & 3.4 & 26.4 & 78.9 \\
\hline $100-120$ & 21.6 & 6 & 3.2 & 3.7 & 6.8 & 6 & 4.4 & 25 & 76.8 \\
\hline $120-150$ & 19.6 & 5.5 & 3 & 3.4 & 6.9 & 6.4 & 4.7 & 26.2 & 75.8 \\
\hline $150-200$ & 16.7 & 5 & 3.1 & 3.1 & 6.9 & 7.4 & 5.3 & 26.2 & 73.6 \\
\hline $200-250$ & 13.2 & 4.7 & 3.1 & 2.6 & 7 & 8.7 & 5.6 & 23.5 & 68.4 \\
\hline $250-300$ & 11 & 4.9 & 2.9 & 2.3 & 6.3 & 9.3 & 6.2 & 21.7 & 64.6 \\
\hline $300-400$ & 10.1 & 3.8 & 2.9 & 2.2 & 6.7 & 9.1 & 5.6 & 20.3 & 60.8 \\
\hline$>400$ & 4.7 & 2.7 & 1.7 & 1.2 & 4.2 & 7.5 & 4.5 & 13.9 & 40.4 \\
\hline $\begin{array}{l}0-100 \\
\text { (ultra poor) }\end{array}$ & 25.5 & 5.8 & 3 & 4.3 & 7.1 & 4.7 & 3.1 & 25.9 & 79.4 \\
\hline $0-120$ (poor) & 23.7 & 5.9 & 3.1 & 4 & 7 & 5.3 & 3.7 & 25.5 & 78.2 \\
\hline $\begin{array}{l}>120 \\
\text { (non-poor) }\end{array}$ & 13.5 & 4.6 & 2.8 & 2.6 & 6.4 & 7.9 & 5.2 & 22.8 & 65.9 \\
\hline All & 15.4 & 4.8 & 2.9 & 2.9 & 6.5 & 7.4 & 5 & 23.3 & 68.2 \\
\hline
\end{tabular}


Table 18: Share of non-food items in total expenditure by percentage of the reference poverty line 1990-91

\begin{tabular}{|c|c|c|c|c|c|c|c|}
\hline $\begin{array}{l}\text { Percentage of } \\
\text { poverty line }\end{array}$ & $\begin{array}{c}\text { Fuel and } \\
\text { light }\end{array}$ & Housing & $\begin{array}{l}\text { Clothing and } \\
\text { non-durables }\end{array}$ & $\begin{array}{l}\text { Health and } \\
\text { personal care }\end{array}$ & Education & $\begin{array}{l}\text { Miscellaneous } \\
\text { non-food }\end{array}$ & $\begin{array}{l}\text { All non- } \\
\text { food }\end{array}$ \\
\hline $0-50$ & 6.3 & 3.7 & 4.7 & 1.6 & 1.2 & 1.7 & 19.3 \\
\hline $50-80$ & 5.4 & 4.3 & 5 & 2.2 & 1 & 2 & 20 \\
\hline $80-100$ & 5 & 4.6 & 5.4 & 2.4 & 1.1 & 2.5 & 21.1 \\
\hline $100-120$ & 4.6 & 5.2 & 5.8 & 3.4 & 1.1 & 3.1 & 23.2 \\
\hline $120-150$ & 4.4 & 5.1 & 6.2 & 3.4 & 1.3 & 3.8 & 24.2 \\
\hline $150-200$ & 4.1 & 5.9 & 6.5 & 3.6 & 1.4 & 5 & 26.4 \\
\hline $200-250$ & 3.9 & 8.1 & 7 & 4.1 & 1.7 & 6.8 & 31.6 \\
\hline $250-300$ & 3.7 & 10.5 & 6.9 & 4.4 & 1.9 & 8.1 & 35.4 \\
\hline $300-400$ & 3.7 & 10.3 & 7 & 5 & 2.1 & 11 & 39.2 \\
\hline$>400$ & 3.7 & 22.7 & 5.9 & 6.2 & 2.5 & 18.6 & 59.6 \\
\hline $\begin{array}{l}0-100 \\
\text { (ultra poor) }\end{array}$ & 5.2 & 4.5 & 5.3 & 2.3 & 1.1 & 2.3 & 20.6 \\
\hline $\begin{array}{l}0-120 \\
\text { (poor) }\end{array}$ & 4.9 & 4.8 & 5.5 & 2.8 & 1.1 & 2.6 & 21.8 \\
\hline $\begin{array}{l}>120 \\
\text { (non-poor) }\end{array}$ & 4 & 9.6 & 6.6 & 4.3 & 1.7 & 8.1 & 34.1 \\
\hline All & 4.1 & 8.7 & 6.4 & 4 & 1.6 & 7.1 & 31.8 \\
\hline
\end{tabular}


Table 19: Targeting indices by various indicators 1990-91 (using reference poverty line)

\begin{tabular}{|c|c|c|c|c|c|}
\hline Groups/indicators & $\begin{array}{l}\text { Targeting } \\
\text { indicator } \\
\text { for } \\
\text { additive } \\
\text { transfers }\end{array}$ & $\begin{array}{l}\text { Targeting } \\
\text { indicator } \\
\text { for } \\
\text { multiplicati } \\
\text { ve transfers }\end{array}$ & Groups/indicators & $\begin{array}{l}\text { Targeting } \\
\text { indicator } \\
\text { for additive } \\
\text { transfers }\end{array}$ & $\begin{array}{l}\text { Targeting } \\
\text { indicator } \\
\text { for } \\
\text { multiplicati } \\
\text { ve transfers }\end{array}$ \\
\hline Sri Lanka & 100.0 & 100.0 & & & \\
\hline Sector: & & & Unclassified & 245.9 & 355.0 \\
\hline Rural & 109.3 & 116.7 & Headship: & & \\
\hline Urban & 85.9 & 69.5 & Male-headed & 97.5 & 96.6 \\
\hline Estate & 43.8 & 50.1 & Female-headed & 111.2 & 117.5 \\
\hline Region/sector: & & & Ethnicity: & & \\
\hline Western & 82.2 & 70.6 & Sinhalese & 99.8 & 101.8 \\
\hline urban & 85.1 & 64.6 & Sri Lankan Tamils & 111.6 & 82.5 \\
\hline rural & 79.9 & 77.6 & Indian Tamils & 35.7 & 36.9 \\
\hline Central & 114.7 & 125.1 & Sri Lankan Moors & 133.6 & 130.6 \\
\hline urban & 87.8 & 81.3 & Self-employed in agriculture & & \\
\hline rural & 117.6 & 131.4 & Owning less than 1 acre & 108.3 & 130.1 \\
\hline Southern & 102.3 & 112.6 & Owning $1-3$ acres & 70.5 & 84.9 \\
\hline urban & 88.2 & 83.1 & Owring 3 acres and above & 55.6 & 57.2 \\
\hline rural & 105.2 & 120.1 & Education: of household head: & & \\
\hline N. Western \& N. Central & 101.9 & 110.0 & No schooling & 156.8 & 204.1 \\
\hline urban & 80.3 & 67.9 & $1-5$ years & 132.8 & 158.5 \\
\hline nural & 103.3 & 113.3 & $6-8$ years & 95.6 & 102.6 \\
\hline South central & 112.2 & 120.1 & $9-10$ years & 71.8 & 73.7 \\
\hline urban & 93.2 & 93.7 & $\begin{array}{l}\text { Employment status of } \\
\text { household head: }\end{array}$ & & \\
\hline rural & 113.9 & 123.0 & Employed & & \\
\hline Employment sector: & & & urban & 79.7 & 61.2 \\
\hline Agriculture & 102.1 & 119.0 & rural & 99.2 & 106.1 \\
\hline Mining, quarrying & 181.7 & 186.7 & Unemployed & & \\
\hline Manufac., elec. gas, water & 99.2 & 96.5 & urban & 54.8 & 40.2 \\
\hline Construction & 125.3 & 138.1 & rural & 247.9 & 297.8 \\
\hline $\begin{array}{l}\text { Trade, hotels, finance, } \\
\text { insurance, real estate }\end{array}$ & 89.2 & 74.0 & Outside the labor force & & \\
\hline $\begin{array}{l}\text { Transport, storage, } \\
\text { communicn. }\end{array}$ & 37.6 & 32.7 & urban & 100.0 & 89.4 \\
\hline $\begin{array}{l}\text { Commercial and social } \\
\text { services }\end{array}$ & 64.1 & 54.8 & rural & 115.1 & 123.2 \\
\hline
\end{tabular}

Note: Relatively higher values of the indices imply greater marginal impact of (additive or multiplicative) transfers on the aggregate squared poverty gap measure. 
Table 20: Projected effects of distributionally neutral growth in real per capita consumption on poverty

\begin{tabular}{|c|c|c|c|c|}
\hline \multirow{2}{*}{$\begin{array}{l}\text { Assumed rate of } \\
\text { growth of real } \\
\text { consumption per } \\
\text { capita (\% p.a.) }\end{array}$} & \multicolumn{2}{|c|}{ Lower poverty line } & \multicolumn{2}{|c|}{ Higher poverty line } \\
\hline & 1995 & 2000 & 1995 & 2000 \\
\hline \multicolumn{5}{|c|}{ Headcount index } \\
\hline 0 & 22.36 & 22.36 & 35.34 & 35.34 \\
\hline 2 & 16.24 & 11.54 & 27.61 & 21.3 \\
\hline 3 & 13.79 & 7.53 & 24.49 & 15.5 \\
\hline 4 & 11.54 & 5.56 & 21.46 & 10.75 \\
\hline 5 & 9.26 & 3.83 & 18.14 & 7.3 \\
\hline \multicolumn{5}{|c|}{ Poverty gap index } \\
\hline 0 & 4.82 & 4.82 & 8.8 & 8.8 \\
\hline 2 & 3.33 & 2.24 & 6.43 & 4.55 \\
\hline 3 & 2.75 & 1.52 & 5.45 & 3.15 \\
\hline 4 & 2.26 & 1.03 & 4.59 & 2.13 \\
\hline 5 & 1.86 & 0.68 & 3.84 & 1.46 \\
\hline \multicolumn{5}{|c|}{ Squared poverty gap index } \\
\hline 0 & 1.62 & 1.62 & 3.2 & 3.2 \\
\hline 2 & 1.08 & 0.71 & 2.23 & 1.52 \\
\hline 3 & 0.88 & 0.46 & 1.85 & 1.02 \\
\hline 4 & 0.71 & 0.29 & 1.53 & 0.67 \\
\hline 5 & 0.58 & 0.17 & 1.26 & 0.44 \\
\hline
\end{tabular}

Note: All poverty measures are expressed as percentages. 


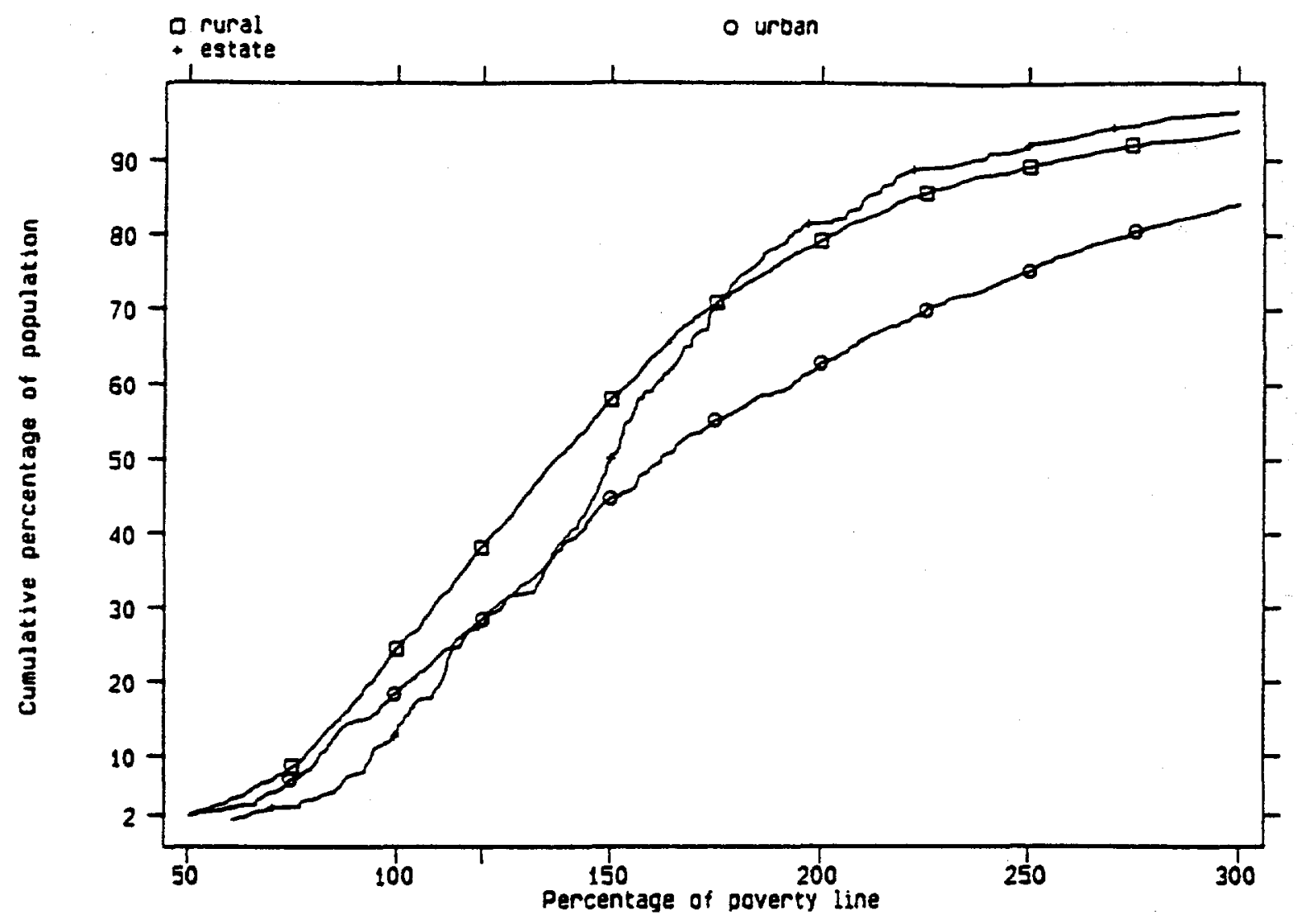

Figure 1: Sectoral Cumulative Distribution Functions 1990-91 


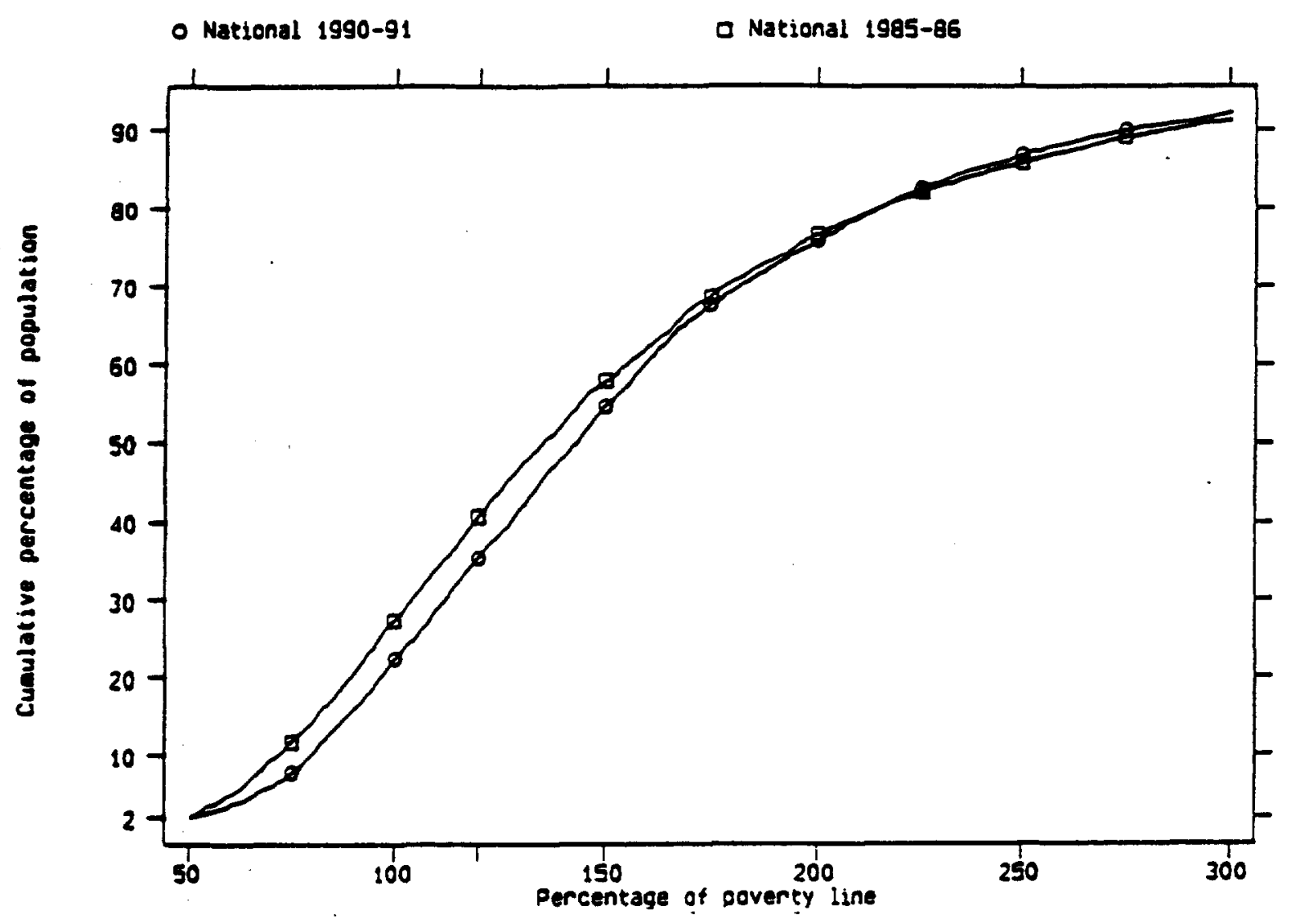

Figure 2: National CDFs: $1985-86$ and $1990-91$ 


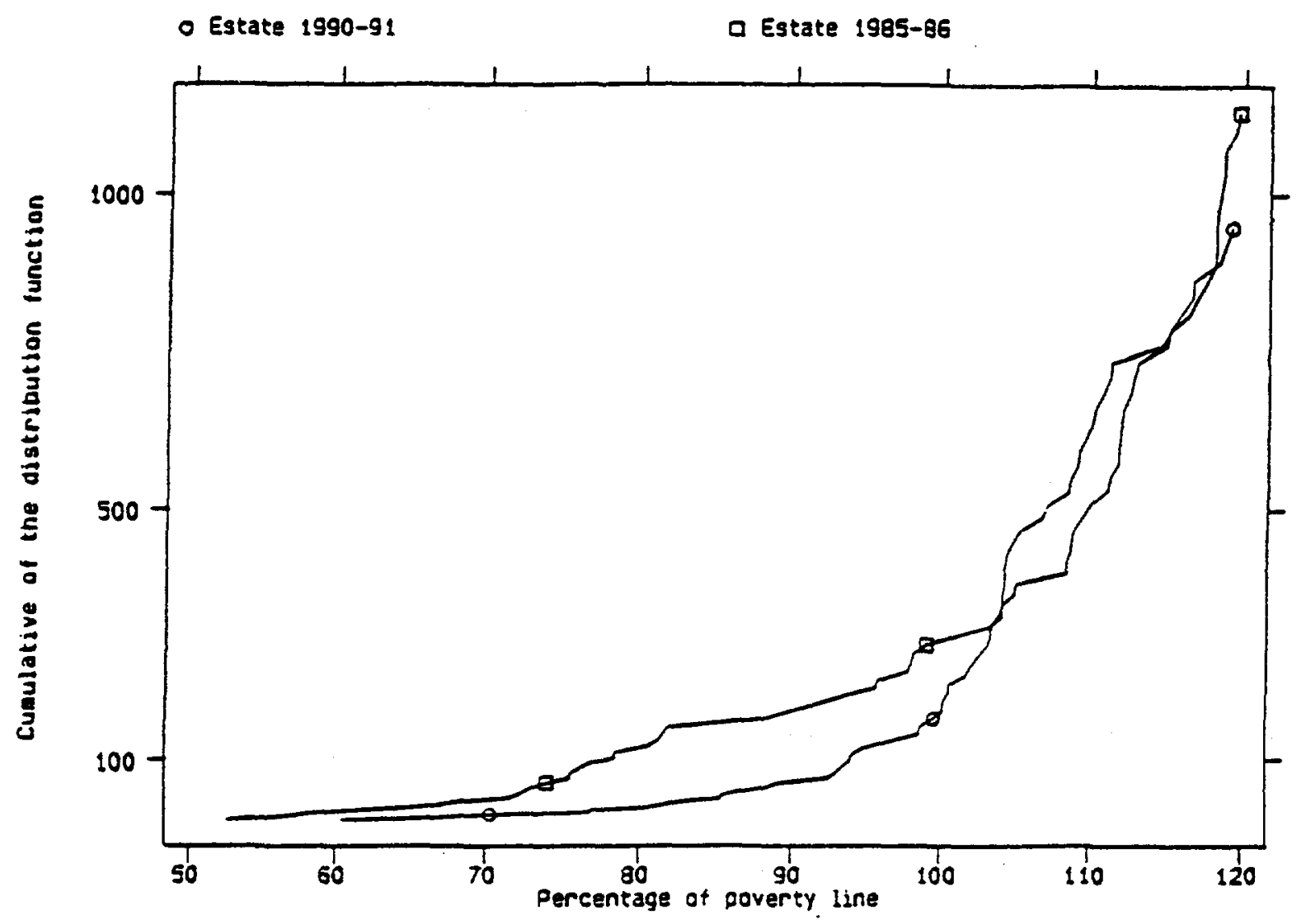

Figure 3: Estate Deficit Curves: $1985-86$ and 1990-91 


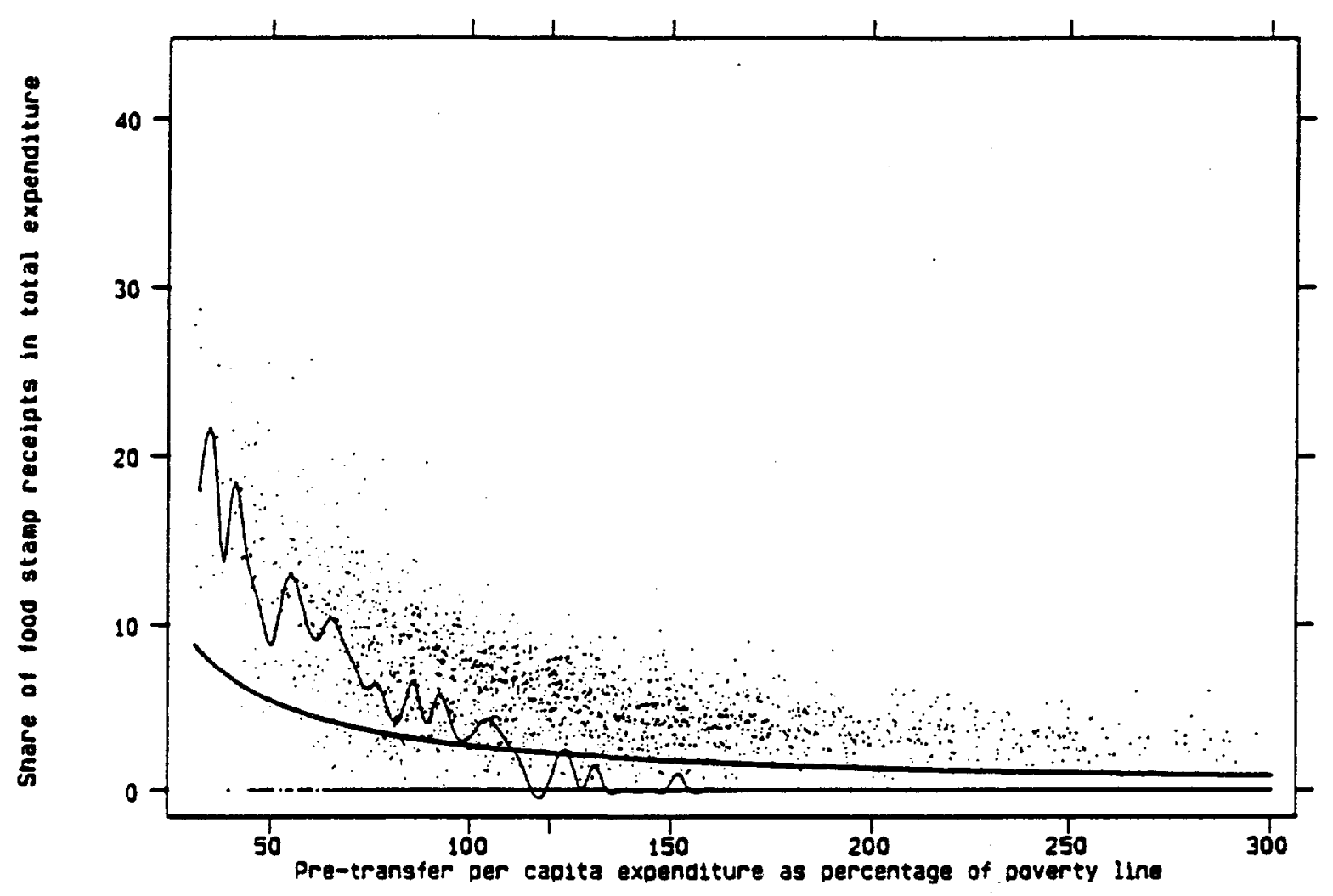

Figure 4: Receipts from the Food Stamp Program: National 


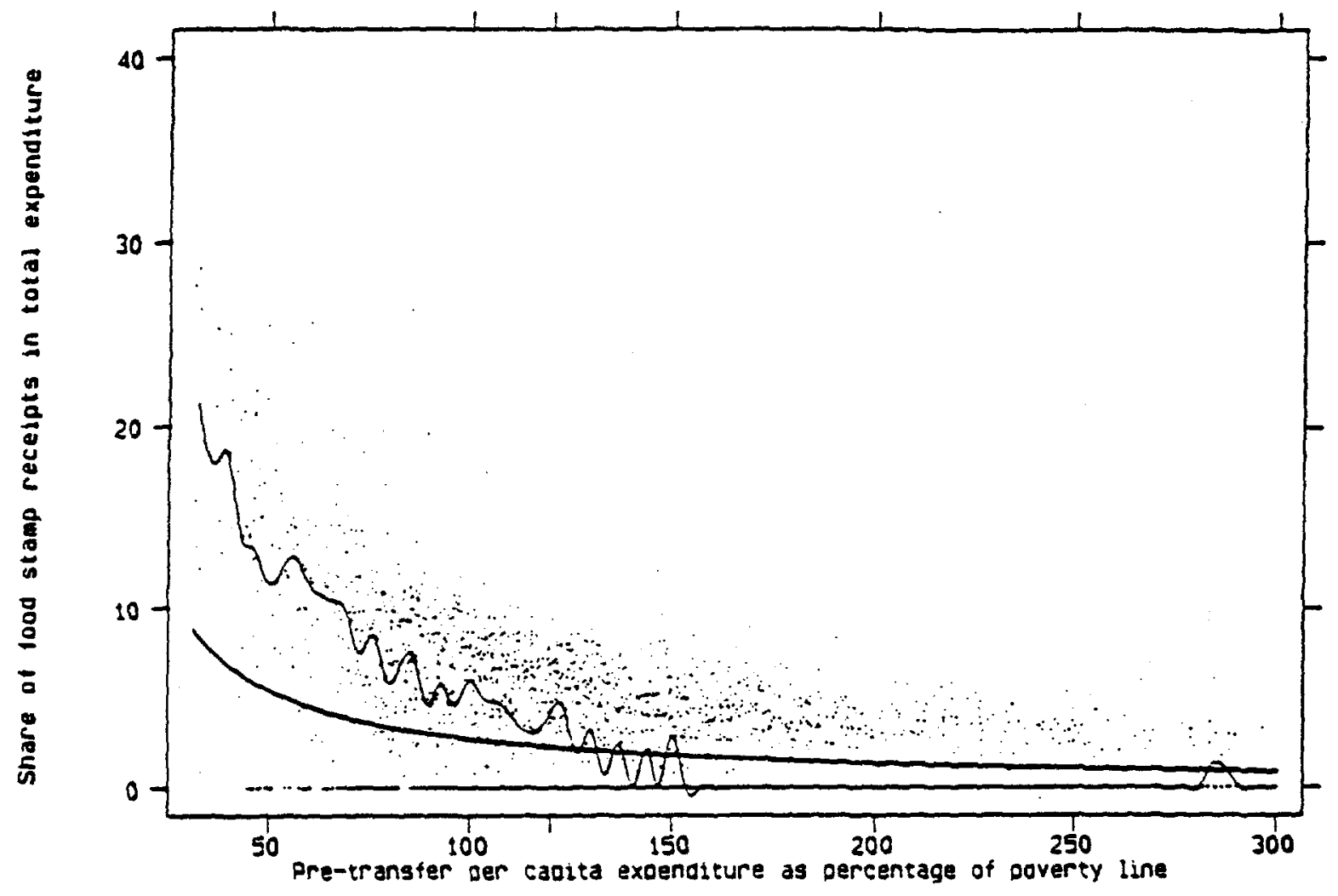

Figure 5: Receipts from the Food Stamp Program: Rural + Estate 


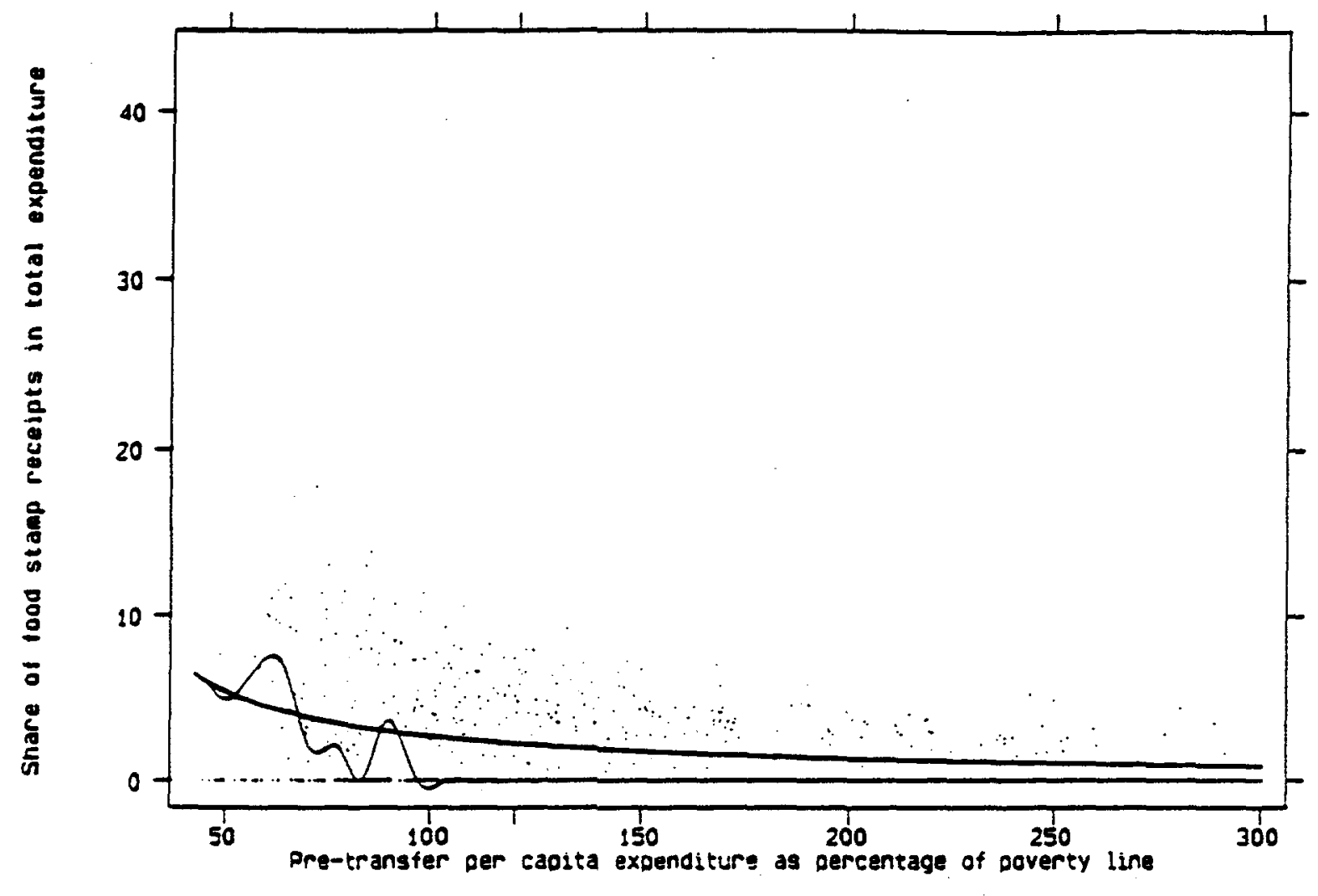

Figure 6: Receipts from the Food Stamp Program: Urban 


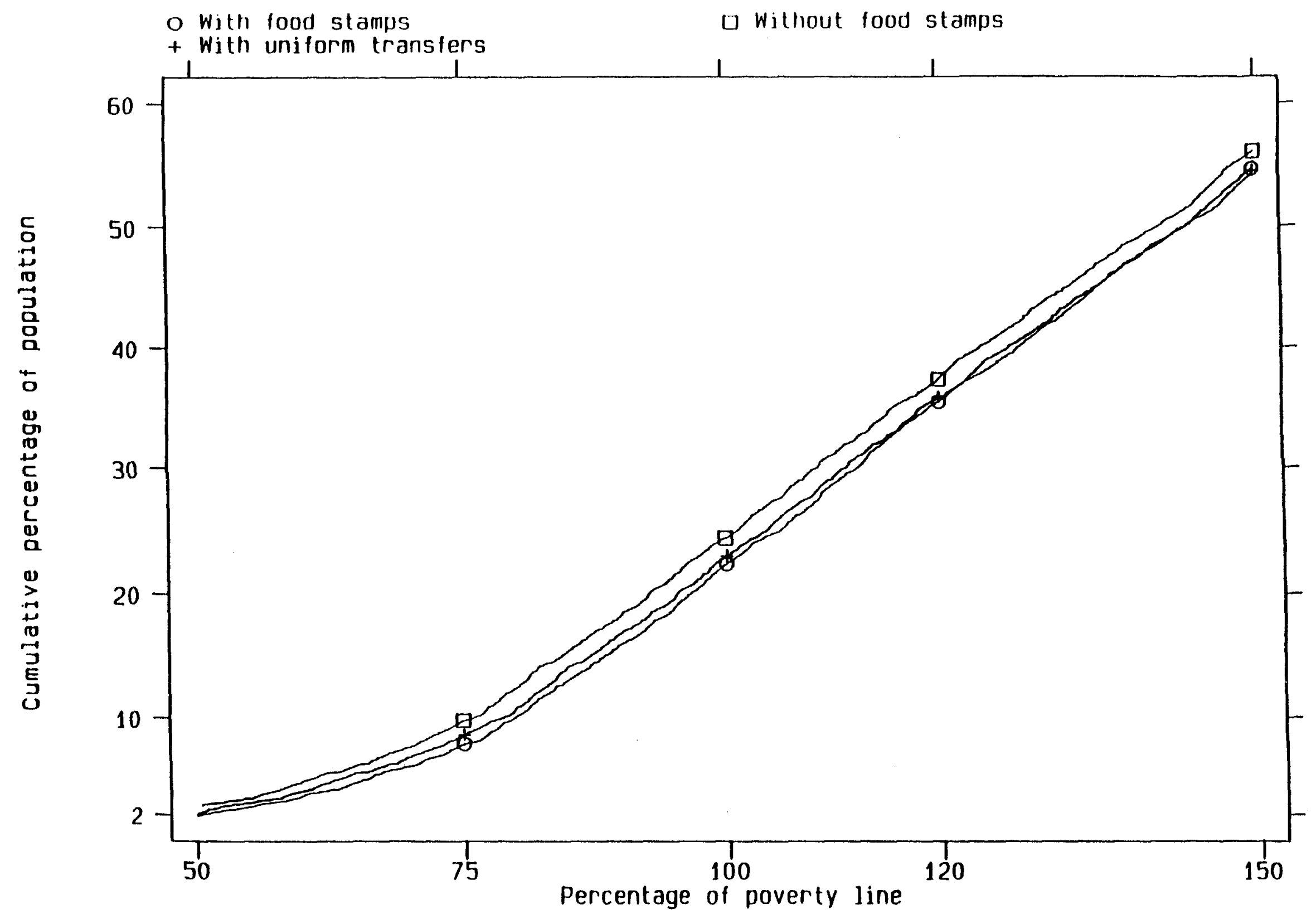

Figure 7: Food Stamps and Uniform Transfers: National CDFs 1990-91 


\section{Policy Research Working Paper Series}

Title

WPS1719 Shifting Responsiblity for Social Services As Enterprises Privatize in Belarus

WPS1720 The Distribution of Foreign Direct Investment in China

WPS1721 EU Accession of Central and Eastern Europe: Bridging the Income Gap

WPS1722 Uncertainty, Instability, and Irreversible Investment: Theory, Evidence, and Lessons for Africa

WPS1723 The Productivity Effects of of Decentralized Reforms: An Analysis of the Chinese Industrial Reforms

WPS1724 Debt Maturity and Firm Performance A Panel Study of Indian Companies

WPS1725 Access to Long-Term Debt and Effects on Firms' Performance: Lessons form Ecuador

WPS1726 Roads, Population Pressures, and Deforestation in Thailand, 1976-89

WPS1727 The Economics of the Informal Sector: A Simple Model and Some Empirical Evidence from Latin America

WPS1728 Regional Labor Markets during Deregulation in Indonesia: Have the Outer Islands Been Left Behind?

WPS1729 Does Mercosur's Trade Performance Raise Concerns about the Effects of Regional Trade Arrangements?

WPS1730 Have Trade Policy Reforms Led to Greater Openness in Developing Countries?

WPS1731 Pension Reform, Growth, and the Labor Market in Ukraine
Author

David Seweli

Harry G. Broadman

Xiaolun Sun

Luca Barbone

Juan Zalduendo

Luis Servén

Lixin Colin $x u$

Fabio Schiantarelli

Vivek Srivastava

Fidel Jaramillo

Fabio Schiantarelli

Maureen Cropper

Charles Griffiths

Muthukumara Mani

Norman V. Loayza

Chris Manning

Alexander Yeats

Shuby Andriamananjara John Nash

Michelle Riboud

Hoaquan Chu
February 1997

February 1997

Contact

for paper

c. Lawronce 32216

February 1997

J. Grigsby 82423

February 1997

L. Barbone 32556

February 1997

E. Khine 37471

February 1997

P. Sintim-Aboagy 38526

February 1997

B. Moore 38526

February 1997

B. Moore 38528

February 1997

A. Maranon 3907 A

R. Mamin 39026

February 1997

J. Istael 85147

February 1997

4. Ngaina 37947

February 1997

1. Ngaine

37959

February 1997

R. Hablero 33979 


\section{Policy Research Working Paper Series}

\begin{tabular}{|c|c|c|c|c|}
\hline & Title & Author & Date & $\begin{array}{l}\text { Contact } \\
\text { for paper }\end{array}$ \\
\hline WPS1732 & $\begin{array}{l}\text { Agricultural Trade and Rural } \\
\text { Development in the Middle East } \\
\text { and North Africa: Recent Deveiopment } \\
\text { and Prospects }\end{array}$ & $\begin{array}{l}\text { Dean A. DeRosa } \\
\text { its }\end{array}$ & February 1997 & $\begin{array}{l}\text { J. Ngaine } \\
37959\end{array}$ \\
\hline WPS 1733 & $\begin{array}{l}\text { The Usefulness of Private and Public } \\
\text { Information for Foreign Investment } \\
\text { Decisions }\end{array}$ & $\begin{array}{l}\text { Yuko Konoshita } \\
\text { Ashoka Mody }\end{array}$ & February 1997 & $\begin{array}{l}\text { R. Reff } \\
34815\end{array}$ \\
\hline WPS1734 & $\begin{array}{l}\text { Are Markets Learning? Behavior in } \\
\text { the Secondary Market for Brady } \\
\text { Bonds }\end{array}$ & $\begin{array}{l}\text { Luca Barbone } \\
\text { Lorenzo Forni }\end{array}$ & February 1997 & $\begin{array}{l}\text { L. Barbone } \\
32556\end{array}$ \\
\hline WPS1735 & $\begin{array}{l}\text { Competition Policy and the Global } \\
\text { Trading System: A Developing-Countr } \\
\text { Perspective }\end{array}$ & $\begin{array}{l}\text { Bernard Hoekman } \\
y^{\prime}\end{array}$ & March 1997 & $\begin{array}{l}\text { J. Ngaine } \\
37949\end{array}$ \\
\hline WPS1738 & $\begin{array}{l}\text { Creating Incentives for Private } \\
\text { Infrastructure Companies to Become } \\
\text { More Efficient }\end{array}$ & $\begin{array}{l}\text { Ian Alexander } \\
\text { Colin Mayer }\end{array}$ & March 1997 & $\begin{array}{l}\text { R. Schneiderman } \\
30191\end{array}$ \\
\hline WPS 1737 & $\begin{array}{l}\text { Ownership and Corporate } \\
\text { Governance: Evidence from the } \\
\text { Czech Republic }\end{array}$ & $\begin{array}{l}\text { Stijn Claessens } \\
\text { Simeon Djankov } \\
\text { Gernard Pohi }\end{array}$ & March 1997 & \\
\hline WPS1738 & $\begin{array}{l}\text { Some Aspects of Poverty in Sri } \\
\text { Lanka: } 1985-90\end{array}$ & $\begin{array}{l}\text { Gaurav Datt } \\
\text { Dileni Gunewardena }\end{array}$ & March 1997 & $\begin{array}{l}\text { A. Ramirez } \\
85734\end{array}$ \\
\hline
\end{tabular}

